\title{
Religious Interdependence in The "Diwan Nadhmi Al-Aqdein Fi Mad'hi Sayid Alkaounein" By Ibn Jaber Al-Andalusi
}

\author{
Ahmed Abdullah Abid Abbas \\ Al-Anbar Education Directorate, Ministry of Education, Iraq \\ ahmedabdullahaldulaimi@gmail.com
}

\begin{abstract}
:
This study seeks to reveal religious intertextuality in the (Diwan Nadhmi Al-Aqdein Fi Mad'hi Sayid Alkaounein) by Ibn Jaber Al-Andalusi. The research aims to analyze the poetic texts that dealt with the religious text, whether it was a generous Quranic text or an honorable prophetic text. The nature of the research required that it be divided into a preamble and two papers followed by a conclusion and then a list of sources and references. In the introduction, I discussed the march of the term intertextuality, then introducing the poet. With regard to the first topic, intertwining with the Noble Qur'an in two forms. The first is quotation and the second is referral symmetry, and in the second topic I dealt with symmetry with the Prophet's hadith and then mentioned in the conclusion the most important results that I reached through this study.
\end{abstract}

Keywords: $\quad$ Interdependence; Religious; Ibn Jaber; Poetry; Qur'an.

Crossref doi https://doi.org/10.51345/.v31i2.142.g170 


\section{التناص الديني في ديوان نظم العقدين في مدح سيد الكونين لإبن جابر الأندلسي \\ د. أحمد عبدالله عبد عباس \\ مديرية تربية الأنبار، وزارة التربية، العراق \\ ahmedabdullahaldulaimi@gmail.com}

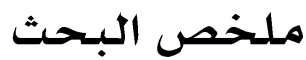

تسعى هذه الدراسة إلى الكثف عن التناص الديني في ديوان نظم العقدين في مدح سيد الكونين لابن جابر الأندلسي، ويهدف البحث إلى تحليل النصوص الشعرية التي تعالقت مع النص الديني سواء أكان نصاً قر آنياً كريحاً أم نصاً نبوياً شريفاً. اقتضت لهت طبيعة البحث أن يقسم على تمهيد ومبحثين تلتها خاتمة ثم قائمة بالمصادر والمراجع. تناولت في التمهيد مسيرة مصطلح التناص، ثم التعريف بالثاعر. فيا تناولت في المبحث الأول التناص مع القرآن الكريم بصورتين. الأول التناص الاقتباس والثانية التناص الإحالي، وفي المبحث الثاني تناولت التناص مع الحديث النبوي الشريف ثم ذكرت في الخاتمة أهم النتائج التي توصلت إليها من خلال هذه الدراسة. 


\section{المقدمة}

يُعد التناص من المصطلحات النقدية الحديثة التي نالت اهتحام الدارسين والمهتمين بالدرس الأدبي تنظيراً وتطبيقاً فقد كُتبت حوله العديد من البحوث والدراسات التي كان لها الدور البارز في إثراء الدرس النقدي الحديث، ورفده بمفاهيم جديدة أسهمت في الكشف عن الابداع وروعته. وقد تلتقي في النصِّ الو احد نصوصٌ متنوعة، وثقافاتُ مختلفة، تتحاورٌ وتتداخل مع بعضها البعض، لتشكّل نصّاً يضمُّ أصو اتاً متعددة، يمكن تمييز ها وتلمسها عبر تقنية التناص. يهدفُ هذا البحث إلى تحليل النصوص الشعرية التي تعالقت مع النص الديني، سواء أكان نصَّاً قرآياً كريحاً أم نصَّاً نبوياً شريفاً. وقد اقتضت طبيعة البحث أنْ يُقسَّم على تمهيدٍ، ومبحثين، تلتها خاتمة ثم قائمة بالمراجع · تناولتُ في التمهيد محورين، ضمَّ المحور الأول حديثاً عن مسيرة مصطلح التناص، منذ بداياته الأولى وحتى لَّ استوائه مصطلحاً نقدياً مستقلاً. وضمَّ المحور الثاني تعريفاً موجزاً بابن جابر الأندلسي، اسمه ونسبه، كُنيته ولقبه، و لادته، حياته العلمية وثقافته، وفاته.

فيما تناولتُ في المبحث الأول، التناص مع القرآن الكريم، بصورتيه المختلفتين، الصورة الأولى: التناص الاقتباسي، والصورة الأخرى: التناص الإحالي. وبالصورتين أنفسها تناولتُ في المبحث الثاني، التناص مع الحديث النبوي الشريف. ومن ثم ذكرتُ في الخاتمة أهم النتائج التي توصلت إليها من خلال هذه الدراسة. وقد اقتصرت - كما يتضح من عنو ان الدراسة - على ديو ان (نظم العقدين في مدح سيد الكونين يحتويه الديوان من تداخل وتعالق مع النص القرآني الكريم، والحديث النبوي الشريف. الأمر الذي يُشكّل سمةً بارزةً تستحقُّ البحث و التحليل. 


\section{: لغة واصطلاحًا}

\section{التناص لغة:}

جاءت كلمة (التناص) في لسان العرب بمعنى الاتصال "يقالُ : هذه الفلاةُ تناصُ أرضَ كذا ونو اصيها، أي: تتصل بها"(1). وأوردها صاحبُ تاجِ العروس "انتصلَ الرجل انقبض، وتناصَّ القوم ازدموا"(2(). ويقترب هذا المعنى من مفهوم التناص بصيغته الحديثة فازدحام النصوص وتداخلها قريب من اتصالها في نص

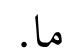

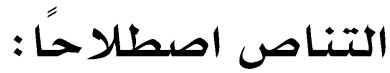

إنَّ مصطلح (التناص) يُعدُّ ترجمةً للمصطلح الفرنسي (int) إذ تعني كلمة (inter) في اللغة الفرنسية: التبادل، في حين تعني كلمة (texte) النص، و أصلُهها الفعل اللاتيني (textere) ويعني (نَسْج) أو (حَبْك) وبهذا يصبح معنى (intertexte): التبادل النصي. وقد ترجمت الى اللغة العربية: بالتناص الذي يعرف بتعالق النصوص بعضها

بعض (3)

إنّ مفهوم التناص لم يتم التعرف عليه بالصورة المعروفة إلّا من خلال (جوليا كريستيفا) وذلك من خلال ما كتبته من أبحاث في سنة 1966، و 1967، ونشرتها في مجلتي (تيل -كيل) و (كريتبك) وهي بهذا تعتبر "صاحبة التوضيح المنهجي الأول لمسألة التناص"(4). وتؤكد جوليا كريستيفا أنَّ كلَّ نصّ هو تناصّ فهي تعرف النص بأنّه "جهازٌ عبر لساني يعيدُ توزيعَ نظام اللغة، بكشفِ العلاقة بين الكلمات التو اصلية"(5).

\section{التهمهيد:}

\section{أولا : التناص، مسيرة مصطلح}

ثمة إجماع بين النقاد والباحثين على أنَّ الناقدة الفرنسية ذات الأصل البلغاري (جوليا كريستيفا) هي أولّ مَنْ صاغ مفهوم التناص، ويعود لها الفضل في اشتقاق المصطلح والترويج له، وذلك من خلال مقالتين لها صدرتا في بجلة تيل كيل (Tel - Quel) و وججلة كريتيك (Critique) (6). 


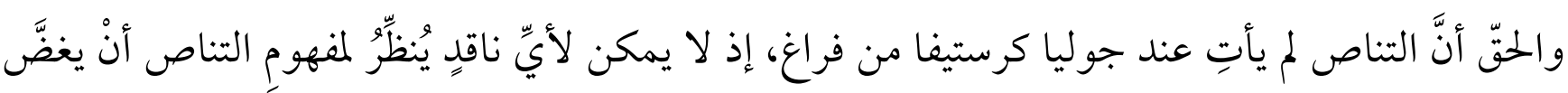

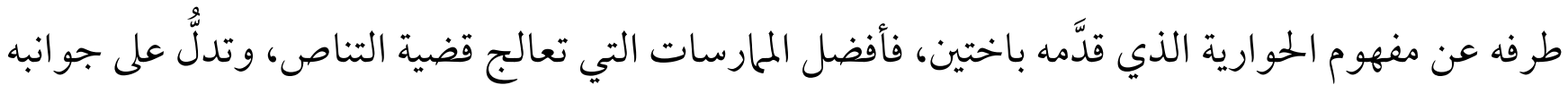

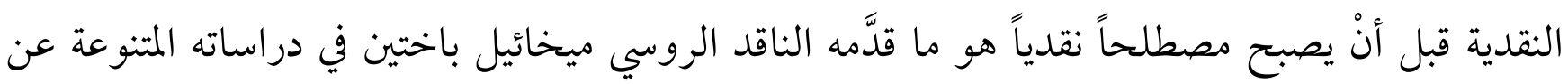
دستويفسكي في بدايات القرن العشرين.

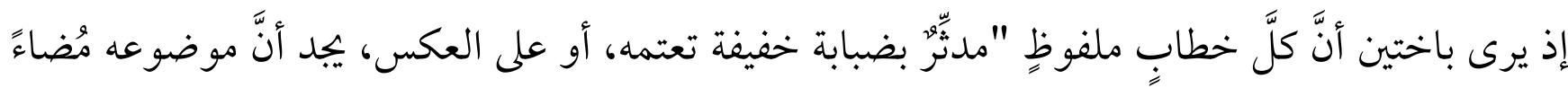

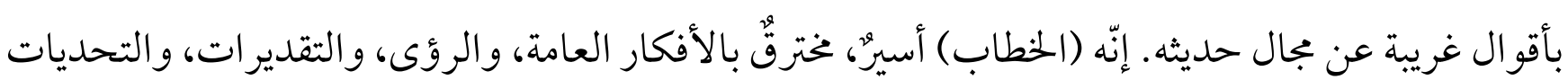
الصادرة عن الاخرين، موجَّهاً نحو موضوعه، يرتاد الخطاب تلك البيئة المكوَّنة من الكلمات الأجنبية، المتهيّجة

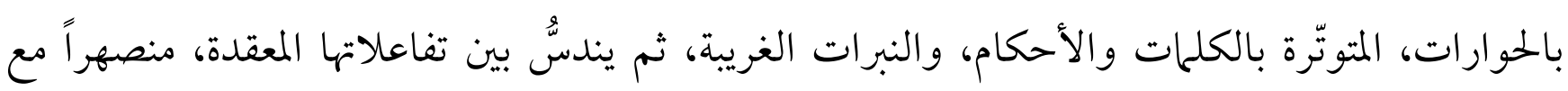

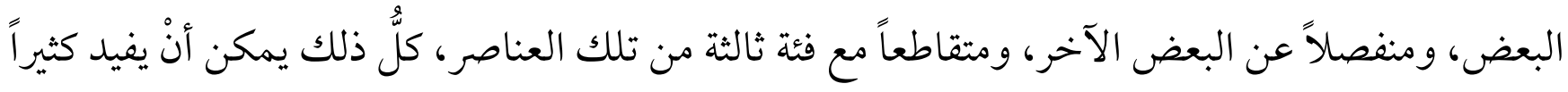

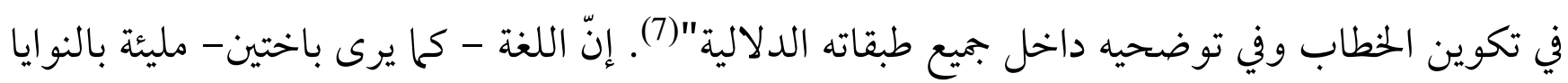

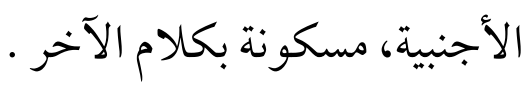

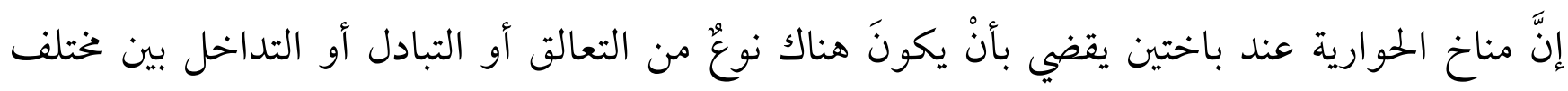

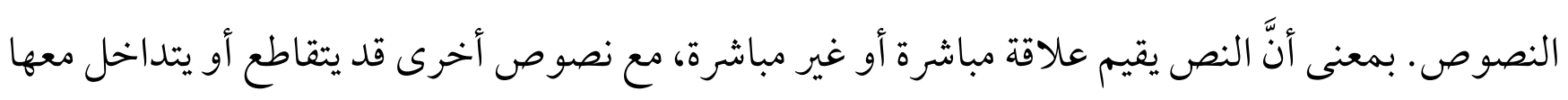
إلى درجة التشابك. وثمة مصدرين آخرين أفادت منها كرستيفا، الأول: هو طروحات العالم فرناند دي سوسير الذي يعدّ بمثابة الأب للمدرسة البنيوية في علم اللسانيات. تقول كرستيفا: "وقد استطعنا مِن خلال مصطلح التصحيف الذي

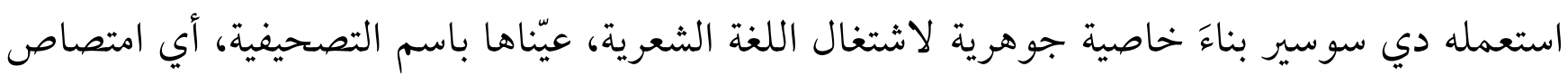

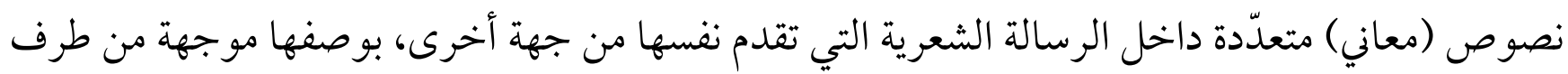

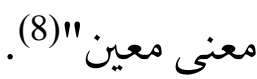


أما المصدر الآخر فهم الشكلانيون الروس، إذ شكَّلتْ آراؤهم جزءاً من الإرهاصات التي مهّدت السبيل

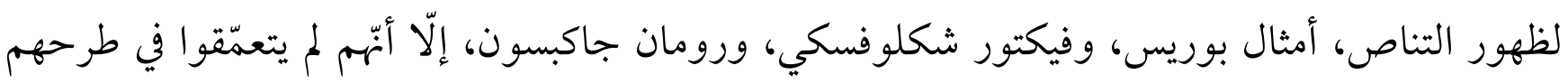

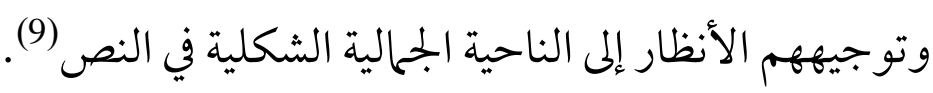

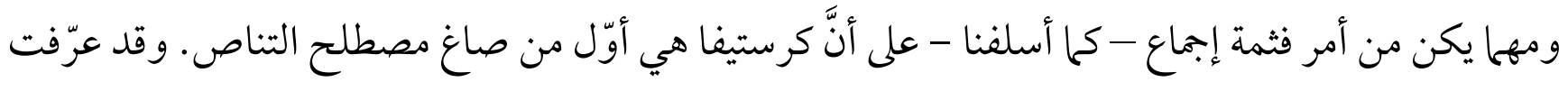
النص بقولها: "جهاز نقل لساني يعيد توزيع نظام اللسان بواسطة الربط بين كلام تو اصلي يهدف إلى الإخبار

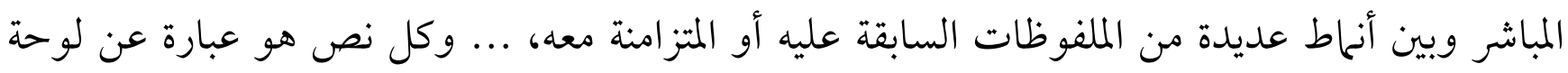

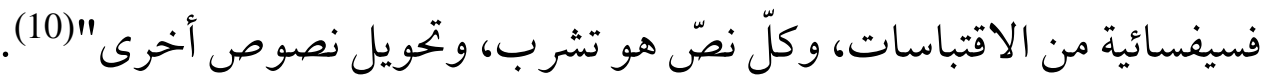

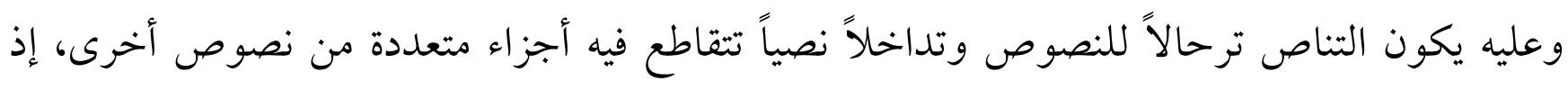
تتفاعل هذه النصوص وتتصارع وتتشابك؛ لتكوّن فضاءُ دلالياً يُيسّده النص الجديد (11).

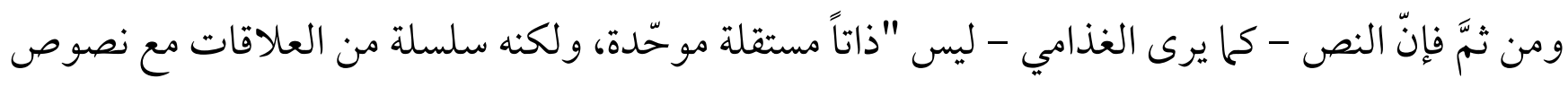

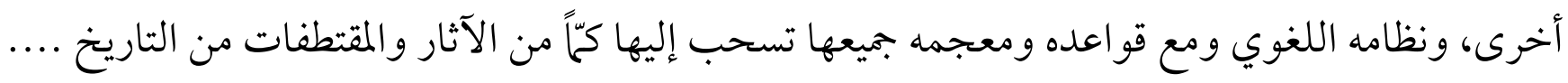

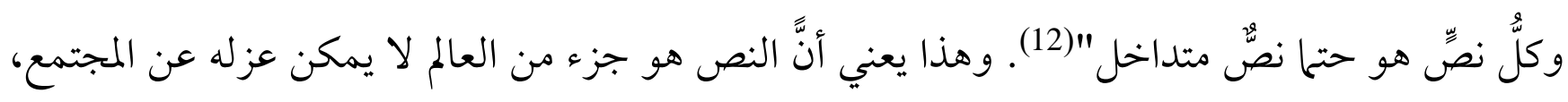

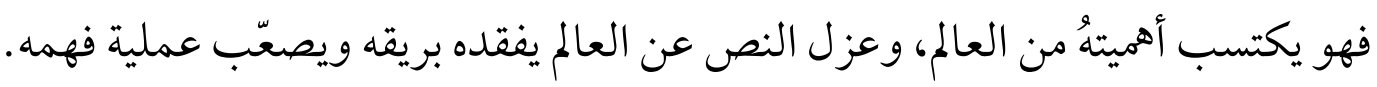

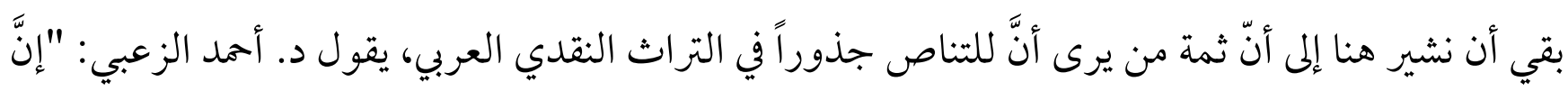

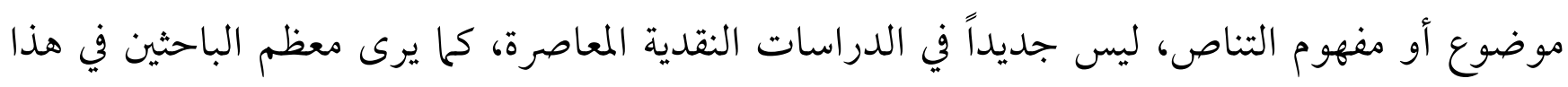

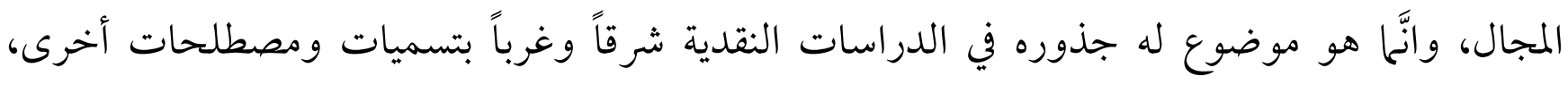
فالاقتباس والتضمين والاستشهاد والقرينة والتشبيه والمجاز والمعنى، وما شابه ذلك في النقد العربي القديم، هي مسائل أو مصطلحات تدخل ضمن مفهوم التناص في صورته الحديثة"(13).

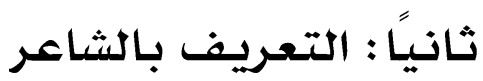

أجمعت كتب التراجم والأنساب العربية على أنَّ اسمه: محمد بن أحمد بن علي بن جابر الهوّاري، الاندلسي،

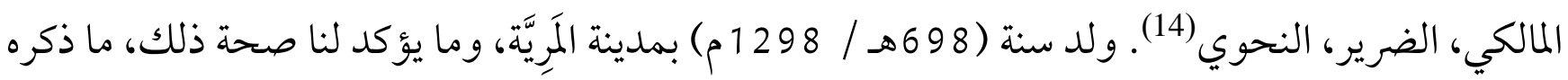


صلاح الدين الصفدي في كتابه (نكت الهِمْيَان في نكت العميان) بقوله: "اجتمعتُ به مرات وسألته عن مولده، فقال: سنة ثحان وتسعين وستحائة بالمريَّة"(15). وينتسبُ ابنُ جابر إلى قبيلة هوَّارة(16)، والنسبة إليها هوَّاري، وهي من بلهيه القبائل التي رحلتُ من المشرق العربي

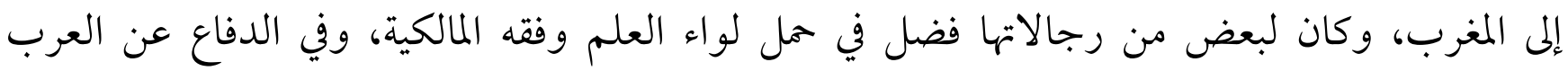
والمسلمين. ويتمي ابنُ جابر إلى بيت علم وفضل وجلالة في الأندلس، فقد نشأ في أسرةٍ متعلمةِ، وكانَ أبوه شيخاً عالماً،

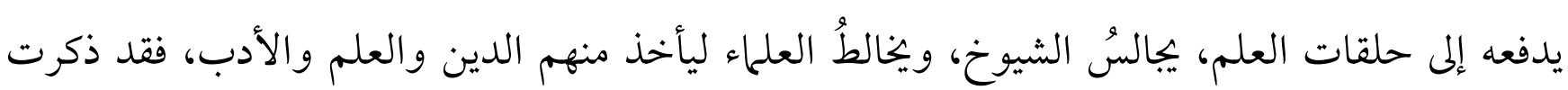

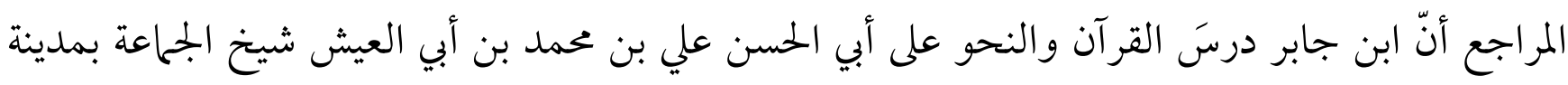

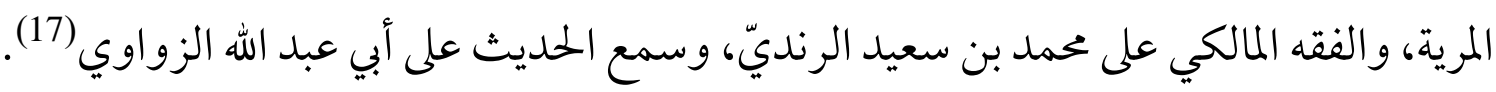

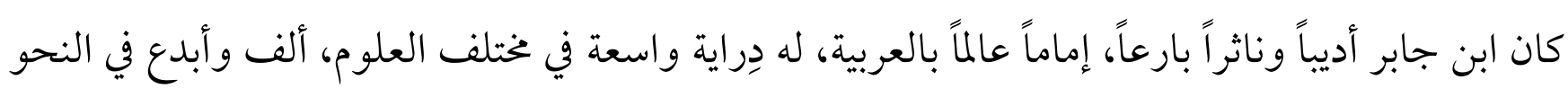
والصرف، والبلاغة، والعروض، واللغة، فضلاً عن براعته الكبيرة في الشعر (18).

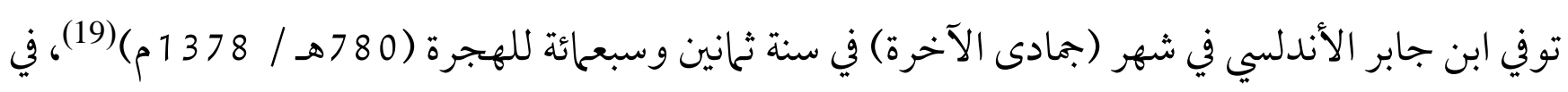
إلبيرة، بالقرب من حلب.

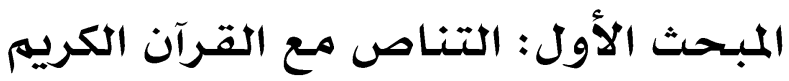

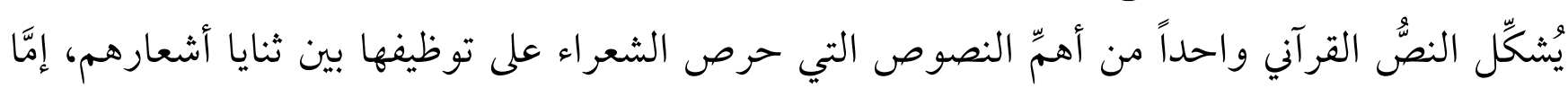

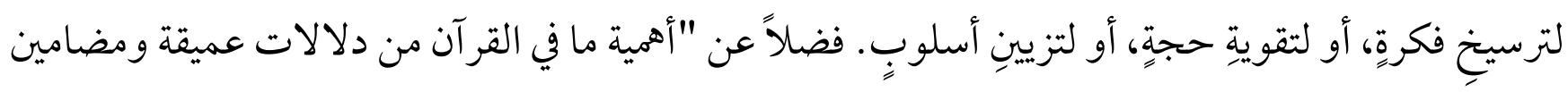

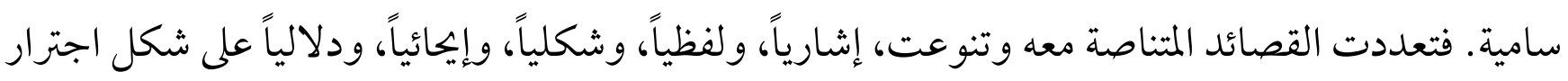

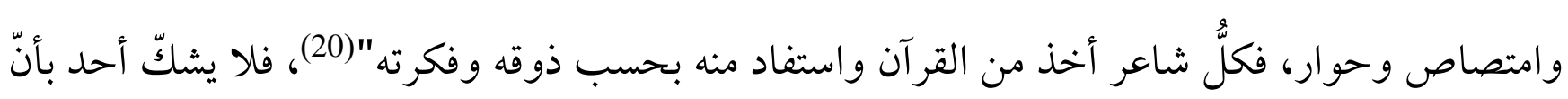
النص القرآني هو أعلى النصوص فصاحة وبلاغة ونظاً. 
ولم يكن شاعرنا (ابن جابر الأندلسي) بِدعاً بين هؤلاء الشعراء، فقد حرص هو الآخر على أنْ ينهل من

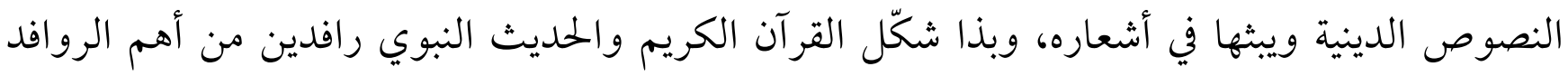
الثقافية التي أغنت أفكار ابن جابر لمِ تمتاز به من الثراء في مدلو لاتها الرامزة.

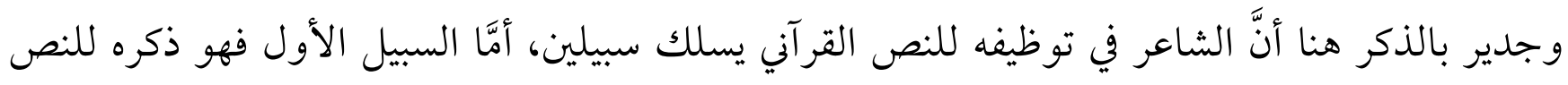

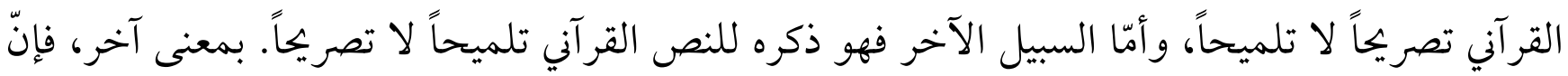
النصوص القرآية تتراءى في شعر ابن جابر بمستويات متفاوتة. وسنسلط الضوء على هذين المستويين، فنسمّي الأول: التناص الاقتباسي، ونسمّي الثاني: التناص الإحالي.

\section{أولا : التناص الاقتباسي}

ويكون النص القرآني هنا متجلياً واضحاً؛ إذ إنَّ الشاعر يعمد الى نصِّ مستقل ومتكامل بذاته، فيقتطعه من

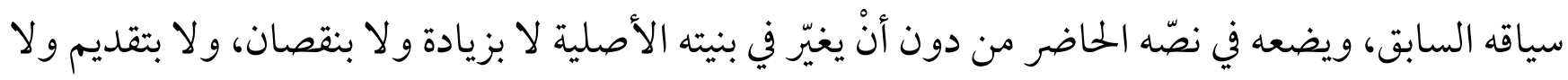
بتأخير.

و الشاعر هنا يلجأ المى طرق آلية من آليات التناص يبدو فيها النص القر آني أكثر وضوحاً، تلك هي آلية أو تقنية الاستشهاد، إذ يورد الشاعر بموجبها النصوص (الاستشهادات) ويضعها بين قوسين أو يستعمل علامات التنصيص للاستدلال وتدعيم خطابه الشعري بشاهد قرآني، وهو ما يمكن تسميته بالتناص الاقتباسي

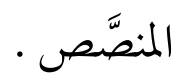
ومن الأمثلة التي نلتمس فيها هذا النوع من التناص في شعر ابن جابر، قولهُ - من المديد (21):

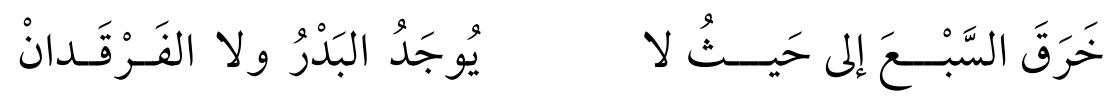

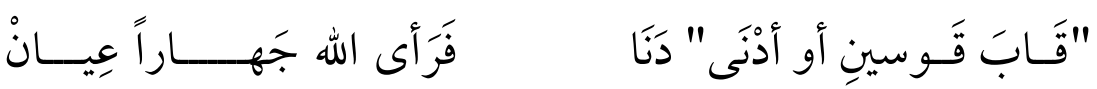

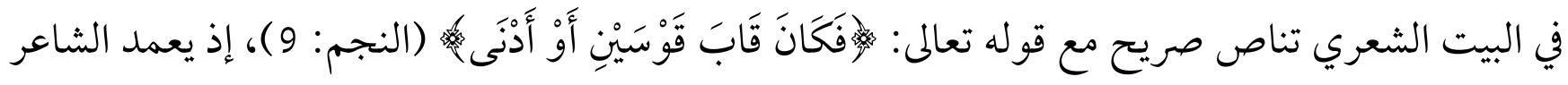

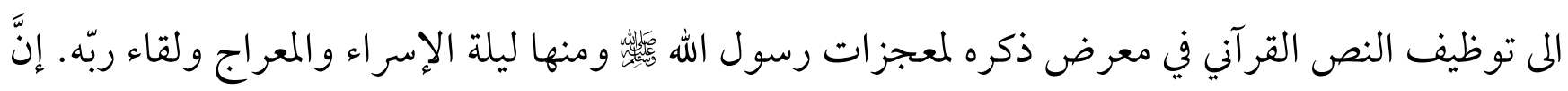


التناص هنا بسيط منصَّص لا يحتاج من المتلقي تأملاً أو إعحالَ فكرِ، فالعبارة القرآية جاءت صريحة من غير تحوير ولا تبديل، ودون تقديم أو تأخير. ومن ذلك أيضا قول الشاعر - من الطويل (22): وجَاوَبَ ربُّ العَرشِ عَنْه عِداتِهِ

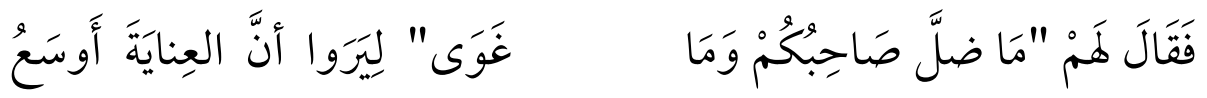

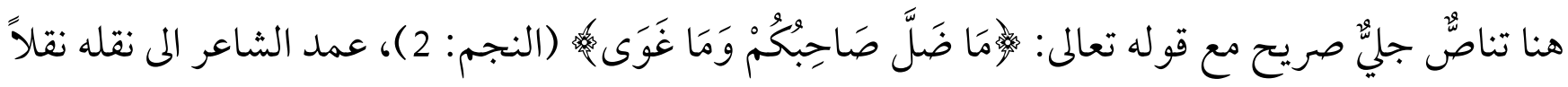

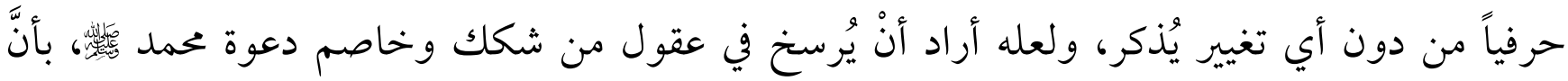
صاحبكم ما حاد عن الحقّ ولا زال عنه، ولكنه على استقامة وسداد. و لا شكَّ أنّ مثل هذه الإشار ات التناصية الواضحة تعطي النص الشعري قوةً وقداسة. ويدخل ضمن التناص الاقتباسي البسيط، النصوص الشعرية التي تعالقت مع النص القرآني صر احةً، لكن مع شيءٍ قليلٍ من التقديم أو التأخير، أو الزيادة أو النقصان، "بها يتفق وسياقات القصيدة الجلديدة، إلّا أنّ طيوف النصّ الأول تظلّ عالقةً في خخيلة القارئ، ولا يمكن إبعادها"(23). ويمكن أنْ نسمي هذا النوع من التناص، بالتناص الاقتباسي المحور، ومن ذلك قول الشاعر - من الطويل (24):

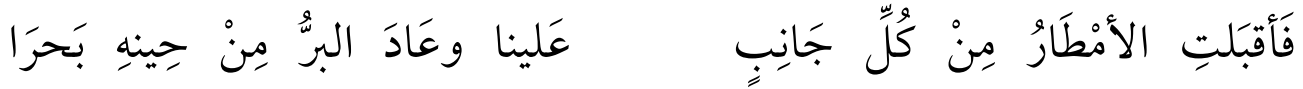

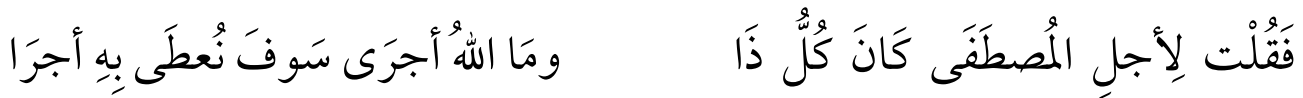

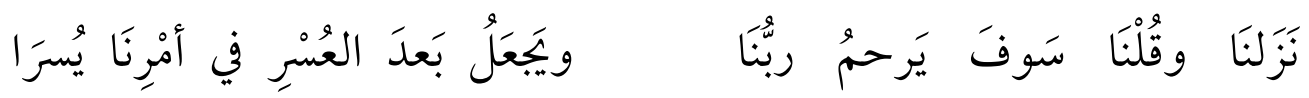
هذا النص من قصيدة لابن جابر طال فيها نفسه الشعري كثيراً حتى تجاوزت أبياتها المئتان، يصف فيها الشاعر رحلته الى رسول الله

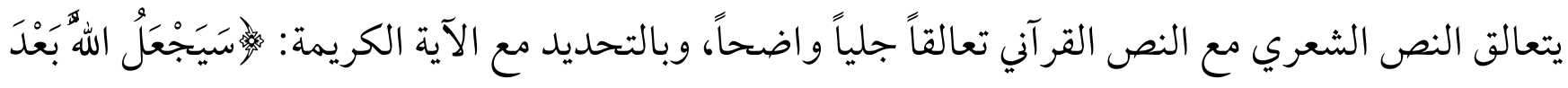

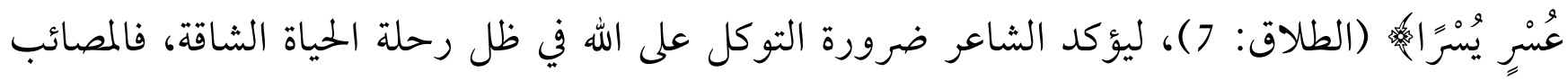
والشدائد حتما ستزول؛ لأنَّا الله حسْبُ من يتوكل عليه. 
إنَّ من يطالع أبيات القصيدة من أوها الى آخرها، ويعيش أجواء تلك الرحلة، سيدرك من دون أيّ عناء أنّّا

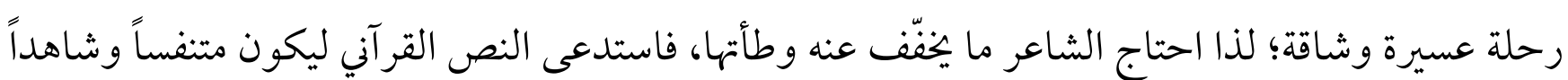
على أنَّ بعد العسر يسراً وفرجاً. وقد يكون التناص بسيطاً لكنّ سمة التحوير فيه تكون أكبر من سابقتها، وربها يكون هناك تطابقٌ في الدلالة،

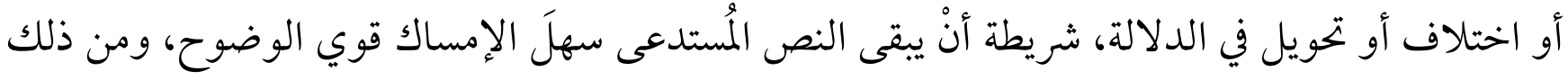
قول الشاعر - من الطويل (25):

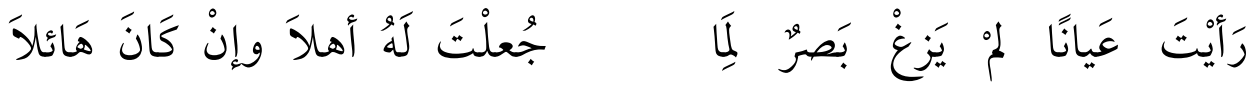

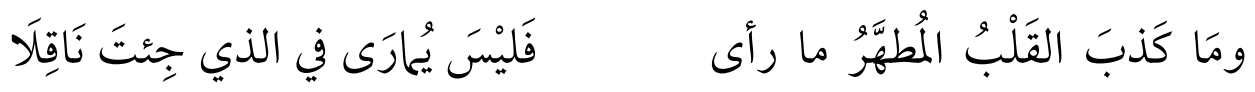

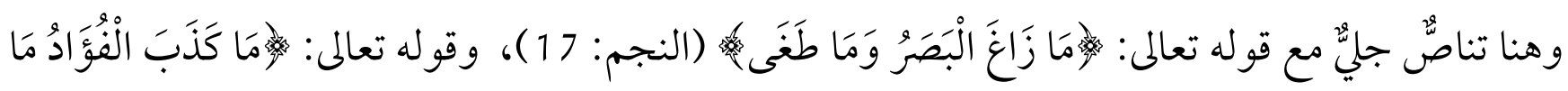

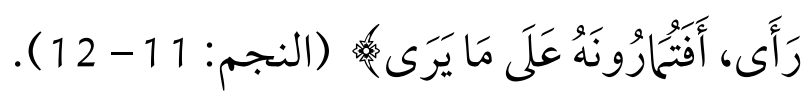
لم يموّر الشاعر في الدلالة، وانها اقتصر تحويره على اللفظ والأسلوب فقط، فاستبدل (الفؤاد) بـ(القلب المطهّر )، واستبدلَ الاسلوب الانشائي بالأسلوب الخبري. ففي النص القرآي أسلوب إنشائي قائم على الاستفهام

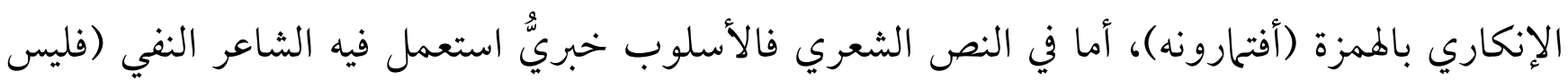

\section{ثانيًاً : التناص الإحالي}

يبدو واضحاً من دلالة المصطلح أنَّ هذا النوع من التناص يقترب من التلميح وينأى عن التصريح، فيذكر

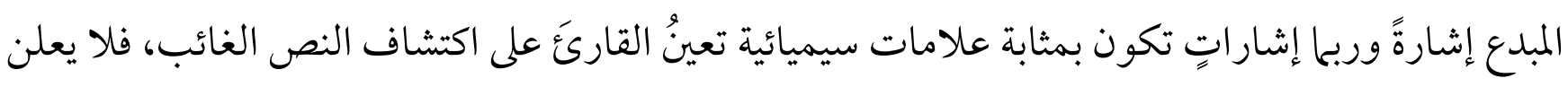

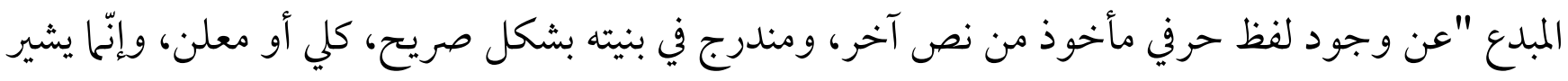

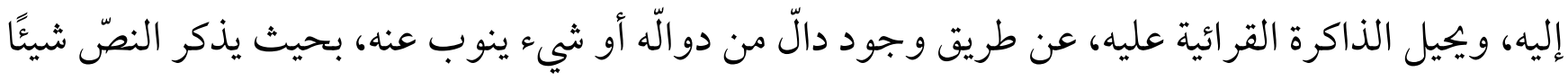
من النصوص السابقة، ويسكت عن بعضها"(26). 
ولعل الشاعر في طرقه لهذه الآلية من التناص يكون أكثر تحررا، بمعنى أنّه لا يتقيد بنقل النص بحرفيته، وإنّما يجد فسحة في المزاوجة بين نصه والنصّ المُستدعى، ليخرج بنصِّ جديدٍ مُكثَّف الدلالة، قوي التأثير، فيكفي الشاعر كلمةً أو كلمتان؛ ليحيل المتلقي الى معرفة النص الغائب الذي قد يأخذ ذكره مساحة كبيرة. ومن أمثلة هذا النوع من التناص في شعر ابن جابر، قوله في مدح رسول لَّل - من الطويل (27):

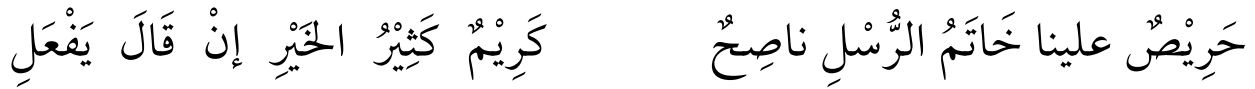

يتحقق التناص الإحالي من خلال اعتحاد ابن جابر على اللفظة القرآنية (حَرِيْصِ)، إذِ يحيلنا من خلالها المى قوله

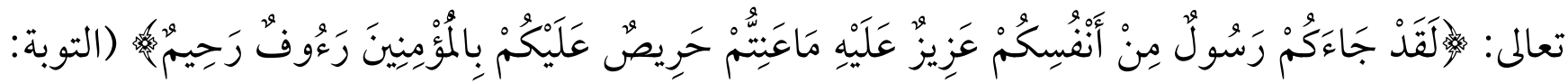

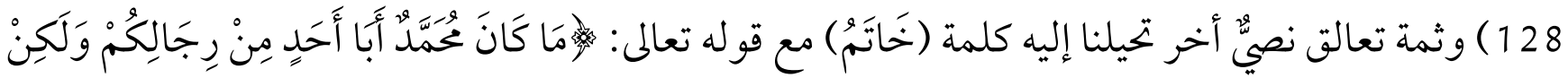

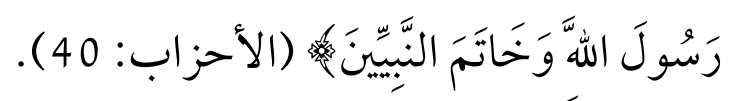

إن الشاعر وهو يعدد مناقب رسول الله شعره. ومن ذلك أيضا قوله - من الطويل (28):

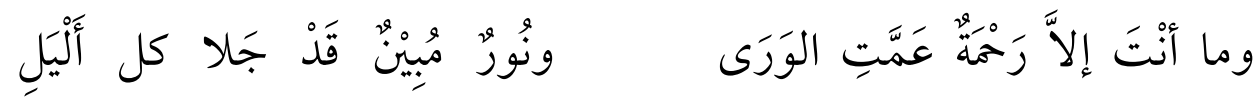

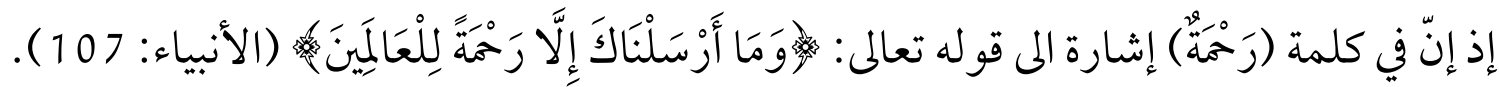
غالبا ما تتعالق نصوص ابن جابر الشعرية مع النص القرآني، بصورة تتلاءم مع تجربته لتعطي مقصدية جلية في النص الشعري، ومن ثم تنسجم مع الفكرة التي يود إيصالها المى القارئ. يقول ابن جابر - من المنسرح(29):

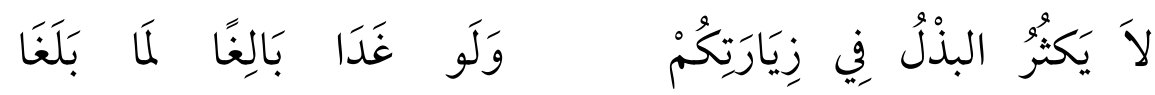

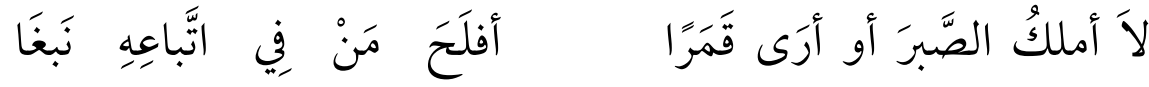
شَفَى وكنَّا عَلَى شَفَا جُروفِ

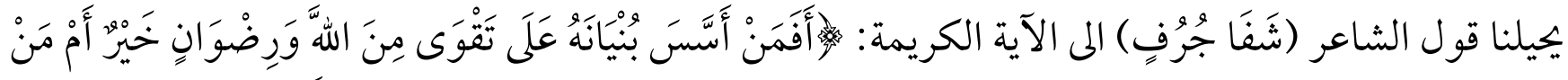

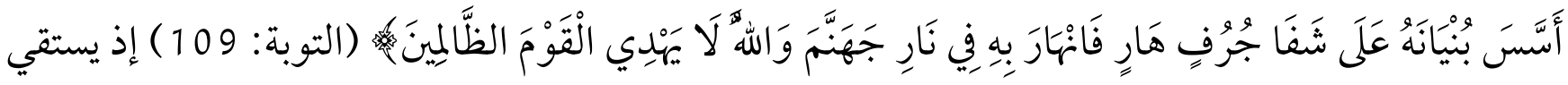
الشاعر من الآية الكريمة دلالة المقابلة بين من أسس بنيانه على قاعدة ثابتة قوية، وبين من أسس بنيانه على 
قاعدة رخوة ركيكة. فقوله (شفا جُرف) تحيل المتلقي إلى التمييز والمقابلة بين التقوى والنفاق، بين الأساس القوي والأساس الضعيف، فمن أراد الفلاح والنجاح فعليه أنْ يتبع نهج الرسول كئسئ. ومن ذلك أيضاً قول الشاعر - من الطويل (30):

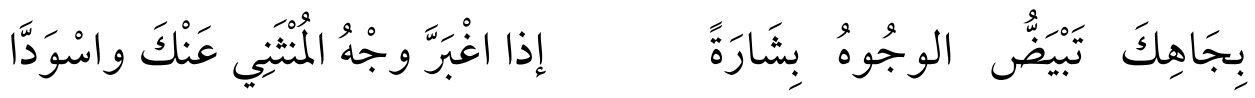

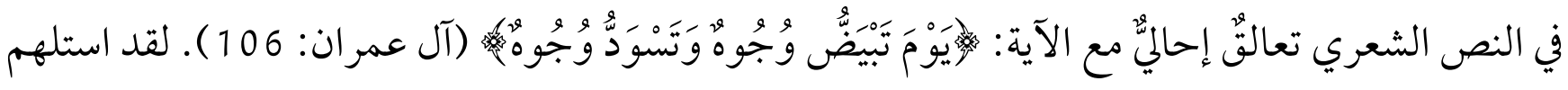
الشاعر الوصف القرآني لأهل الطاعة من تبيض وجوههم يوم القيامة وأهل النفاق من تسود وجوههم، ووظفه في مدح رسول الله وجدير بالذكر هنا أنه قد يأتي - عند ابن جابر - هذا النوع من التناص من دون أن يستعمل لفظاً أو كلمة أو أي تركيب بزوء من آية قرآنية بشكل ظاهر وصريح، وإنها يشير إليه - كما أسلفنا - ويحيل الذاكرة القرائية عليه عن طريق وجود دالّ من دوالّه أو شيءٍ منه ينوب عنه. وقد ضمّت قصيدته الرائية جملة من هذه التعالقات أفاد الشاعر منها في تقديم النصح والارشاد، إذيقول - من البسيط(31):

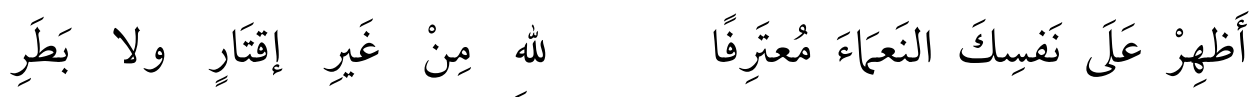
ويقول أيضاً - من البسيط(32):

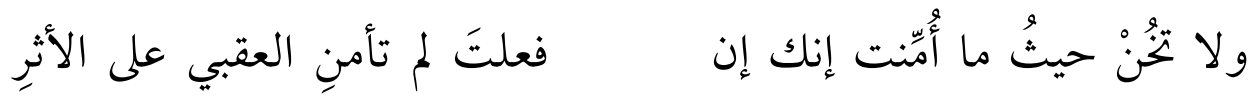
وقوله أيضاً - من البسيط(33):

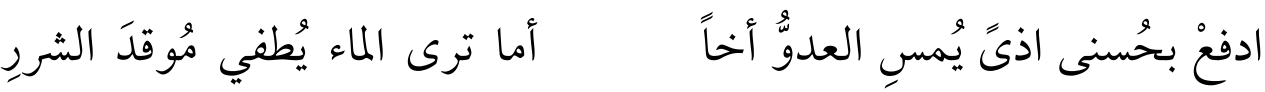
ثمة علامات تحيل المتلقي الى النص القرآني الغائب، فالبيت الأول يُحيلنا إلى قوله تعالى:

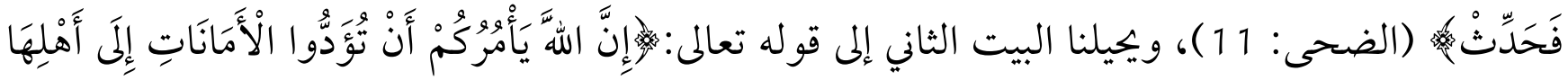

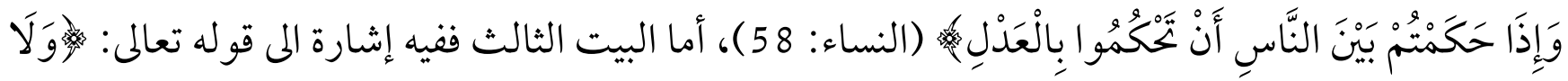

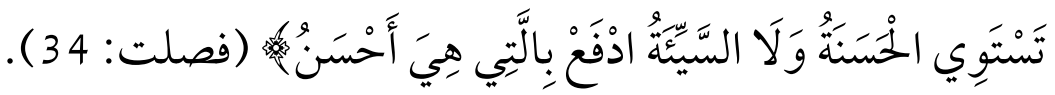


لاشك أن غرض القصيدة استدعى هذا الكمّ من التعالقات النصية القرآنية، فالقصيدة - كما أسلفنا - في الوعظ والإرشاد، وقد وظف الشاعر النص القرآني بكثرة؛ ليعطي لنصه صدقا وتأكيدا وقداسة، وكأنه يُقدّمّ في كل بيت، شاهدا قرآنيا على صدق كلامه.

\section{المبـحث الثاني: التناص مع الحسيث النبوي الشريف} يأتي الحديث النبوي الشريف في المرتبة الثانية، بعد القرآن الكريم من حيث فصاحة اللفظ وبلاغة المعنى، وهو المصدر الثاني من مصادر التشريع الإسلامي، فنصوصه مكملة ومتممة للقرآن الكريم في الأحكام والتشريعات. و الحديث الشريف بها جمع من حكمة وبلاغة وتنوع في الأسلوب كان معين الشعراء الذين اعتنوا بالمصادر الدينية، فأثر في أشعارهم كما أثر القرآن الكريم بها، فاستدعوه في إبداعهم تارة باللفظ وتارة بالمعنى (34) لا يختلف شعر ابن جابر في تعالقاته النصية مع الحديث النبوي الشريف عن تلك التي رأيناها في النص القرآني، فهو هنا يسلك سبيلين أيضاً، فتارة يكون التناص صريحاً جلياً، يتلمسه المتلقي دون عناء أو إعحال فكر، وتارة أخرى يكون خفيا بعض الشيء، تحيلنا إليه بعض الدوال و القرائن، فالأول تناصٌٌ اقتباسيُّ، و الثاني تناصٌّ إحاليّ.

\section{أولا : التناص الاقتباسي}

ثمة أبيات يبدو فيها التناص جليا واضحا، بمعنى أن الشاعر يستدعي الحديث النبوي الشريف بلفظة ومعناه، فيعلن النص السابق (الحديث النبوي الشريف) عن نفسه في بنية النصّ الحاضر الجديد (النصّ الشعري). وسبيل الشاعر هنا كسبيله في التناص الاقتباسي القرآني، فتارة يكون تناصا اقتباسيا نصيا، وتارة أخرى يكون تناصاً اقتباسياً محوّراً، وفي كلا الحالتين لا يجد المتلقي أي جهد في الكشف عن التناص. 


\section{ومن ذلك قول ابن جابر - من المتقارب(35):}

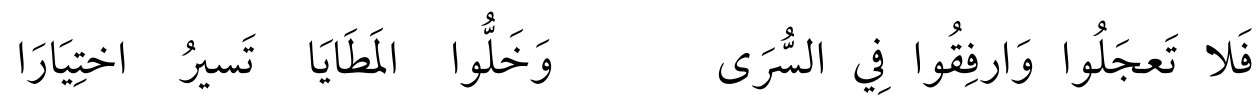

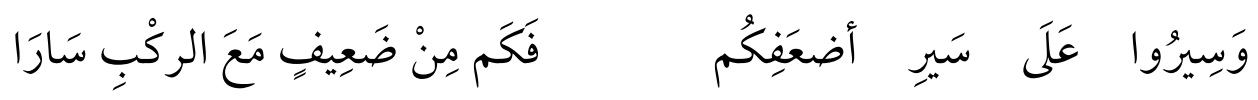

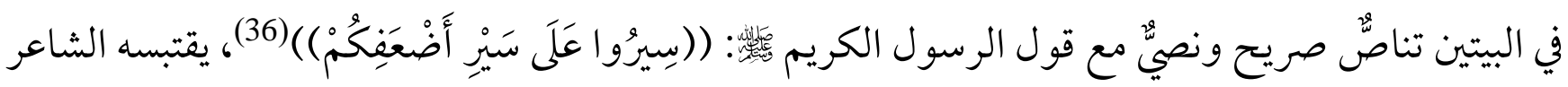
متماثلاً معه في اللفظ والمعنى؛ ليدعم خطابه الشعري، ويؤكده بنصّ من الحديث النبوي؛ لما فيه من قدسية. ومن التناص الأقتابسي قول ابن جابر - من البسيط(37):

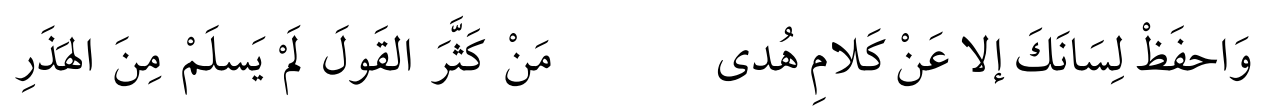

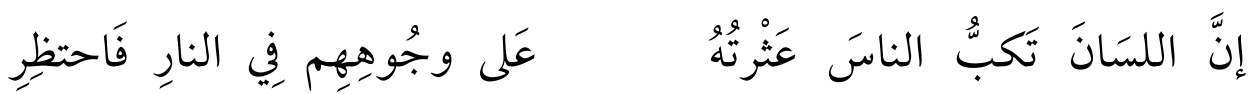

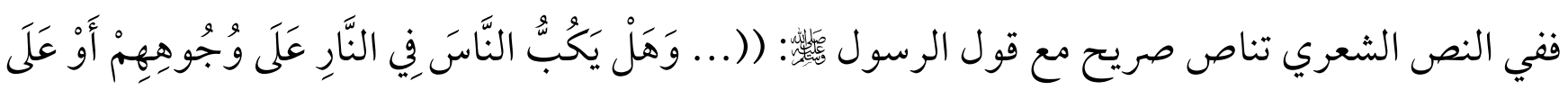

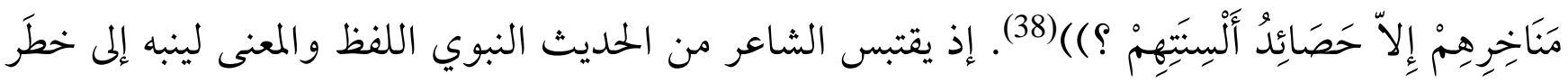
اللسان الجميم، والعواقب المترتبة عليه، مستخدماً أسلوب الأمر (احفظْ - احتضرّ) في محاولة لتوجيه المتلقي إلى الطريق الصحيح في صون لسانه، فيرى أنه لا بدَّ من حفظه عََّّا يضرّ و واستعاله فيها ينفع، و النص أعلاه يأتي في معرض حديث الشاعر عن جملة من الحكم والارشادات. وفي ذكره لفضائل الخلفاء الراشدين رضوان الله عليهم أجمعين، يعمد ابن جابر الم تعضيد كلامه بأحاديث رسول الله ولو أنني من أُمَّني كنتُ آخذاً

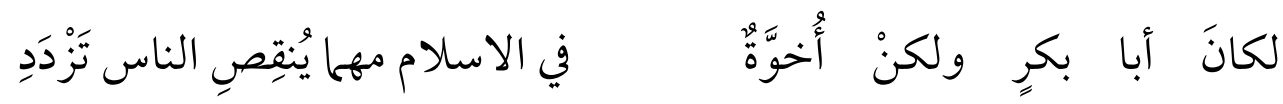

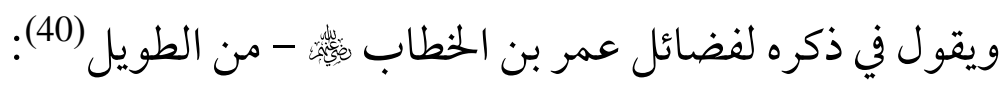

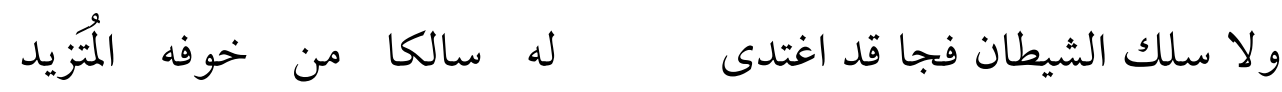


ويقول في ذكره لفضائل عثمان بن عفان هِّئ. - من الطويل (41):

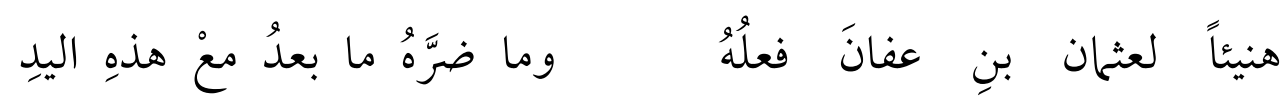

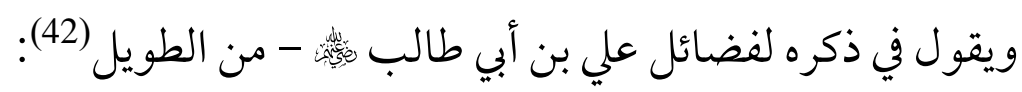

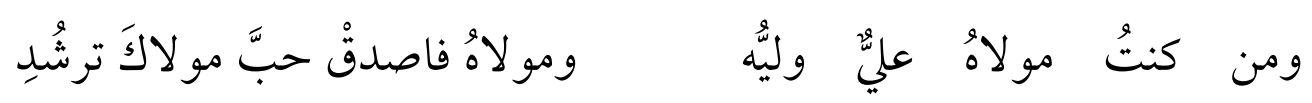

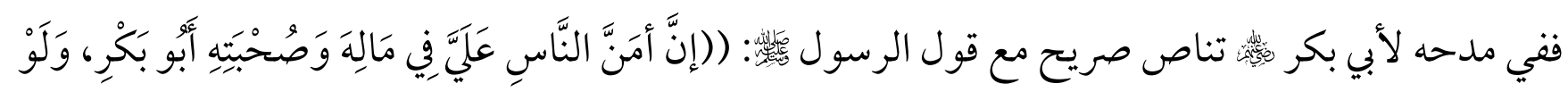

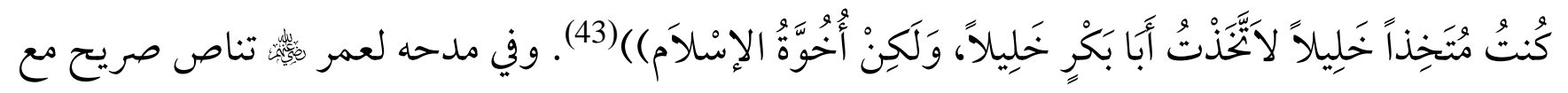
قوله له

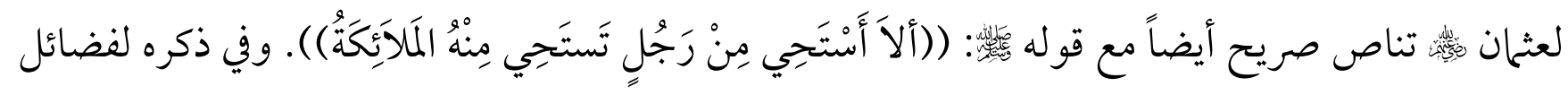

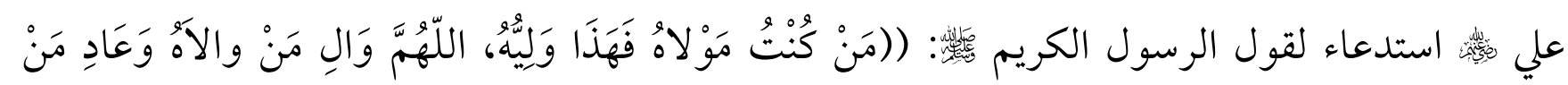
عَادَاهُ() (45)

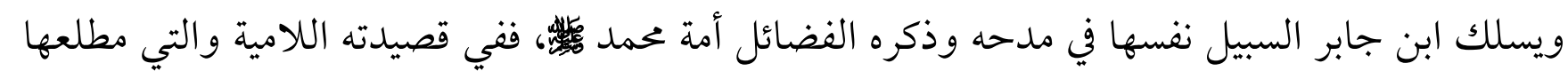
(بانت سعاد فَعِقدُ الصبر محلولُ) - يطلق جملة من فضائل الامة المحمدية، ومنها قوله - من البسيط (46): يا أمَّة المصطفى الهادي لِيْهنبكُمُ

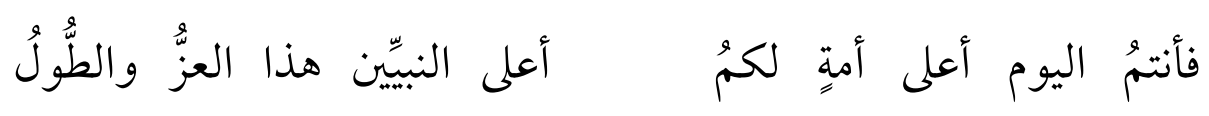

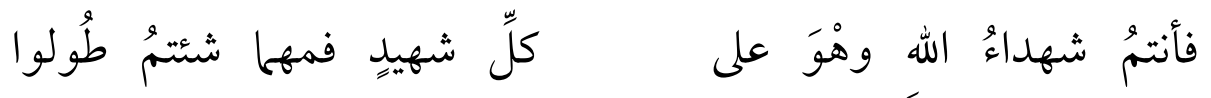
ففي البيت الثالث من النص الشعري تعالقّ نصيٌّ صريح مع قول الرسول الكريم

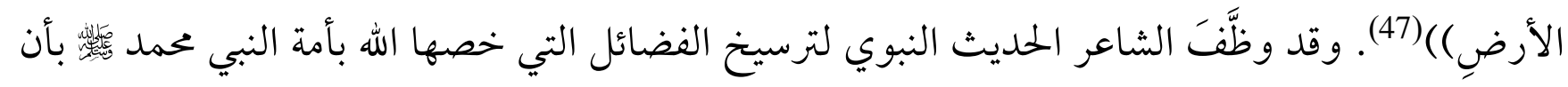
جعلهم خير أمة أخرجت للناس وحباها بأعلى النبيين عزا ورفعة. 


\section{ثانيا : التناص الإحالي}

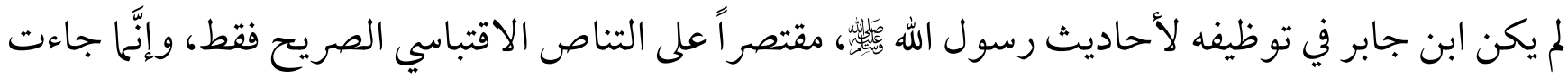
الأحاديث النبوية الشريفة متعالقة مع النصوص الشعرية تعالقاً إحالياً، الأمر الذي أثرى سياقاته التعبرية، ومنحها عمقاً دلاليًا أكثر شمولاً واتساعاً في ذهن المتلقي. ومن التناص الاحالي قول ابن جابر مادحاً رسول الله

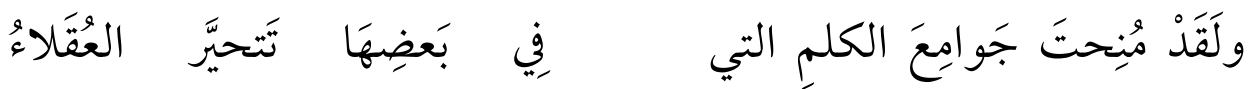

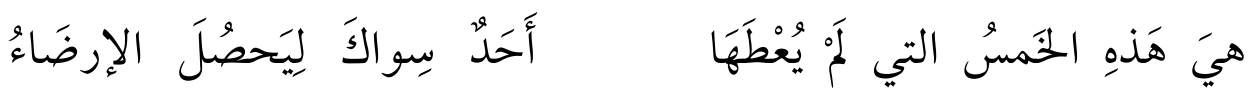

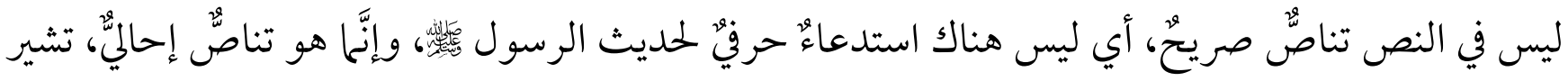

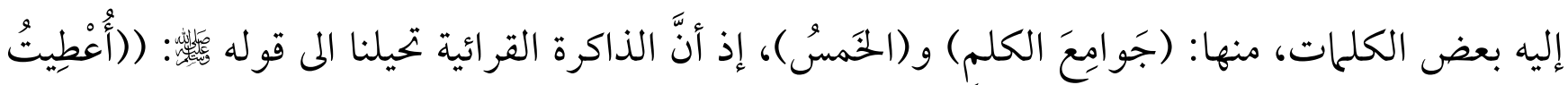

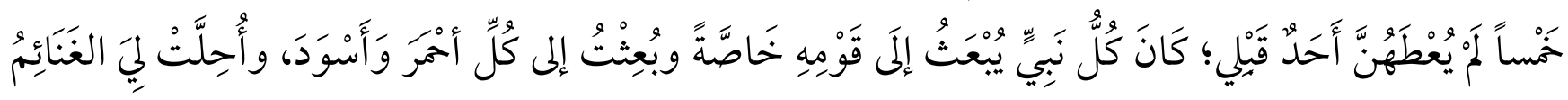

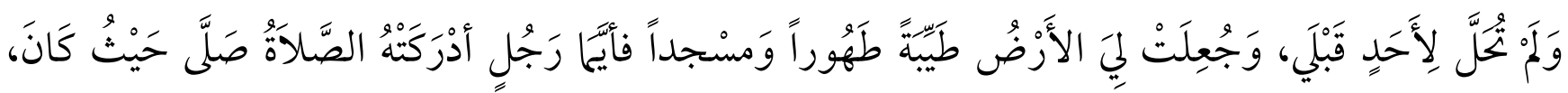

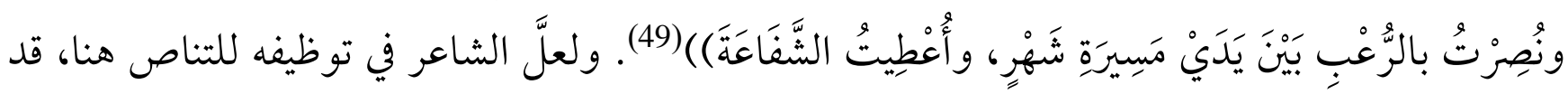
اختصر عدة اسطر في بيتين اثنين، من خلال بثّه لبعض الدوال والقرائن، التي أحالتنا المى الحديث النبوي الشريف.

وغالباً ما يعمد ابن جابر الم هذا النوع من التناص، لا سيا عندما يكون حديثه في النصح والارشاد، ومن ذلك قوله ناصحاً - من البسيط(50): مالي أراكَ مقيماً لا تسارعُ في إعدادِ زادٍ وقد آذنتَ بالسفرِ خذْ من فراغك قبلَ الشغلِ مجتهداً ومنْ حياتك قبل الموتِ واختصِِ

في البيتين تعالق إحاليٌّ مع قول الرسول الكريم

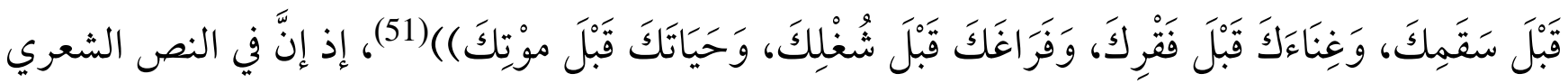


إشارة المى الحديث المذكور، دلَّ عليه سياق النص، وقد وظَّفه الشاعر بجا يتلاءم مع موضوع النصح الذي شكَّل

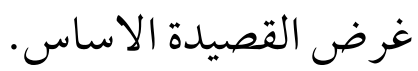
ومن نماذج التناص الإحالي مع نصوص الحديث النبوي، ما جاء في دعوة اين جابر إلى زيارة القبر الشريف، إذ

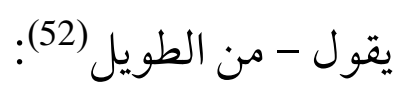

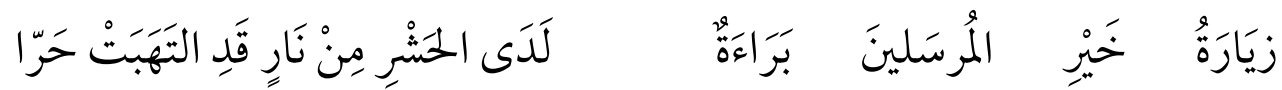
يقيم الشاعر في البيت اعلاه علاقة تناص إحالي، إذي يحيلنا في قوله (زيارة خير المرسلين براءة) إلى حديث

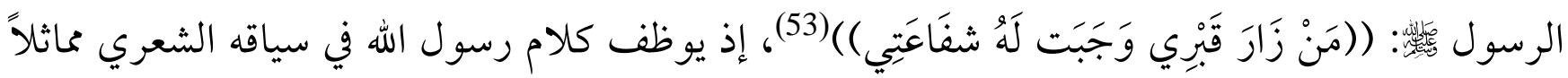
ومطابقا السياق الحديث النبوي في الحث إلى زيارة مكانه الطاهر عليه الصلاة و السلام، وتذكير المؤمن بالأجر

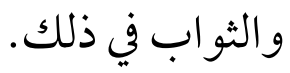

\section{الخاتمة}

بعد أنْ أكر منا الله تعالى بإتمام هذا البحث لا بدّ من تسجيل بعض النتائج، لها بالآتي:

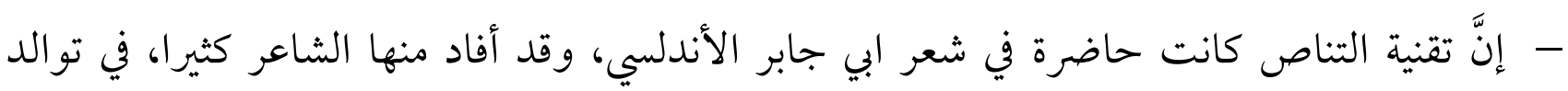
النصوص وتناسقها وفق بناء النص وإنتاجه من نص سابق.

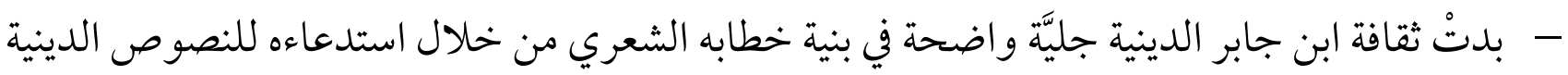
المختلفة، وتوظيفها بها يتلاءم وموضوع القصيدة الأساس. - لم يكن الثناص الديني في شعر ابن جابر سمة عابرة، وإنّمّا شكّل ظاهرة تستحق الوقوف؛ كمّاً ونوعاً

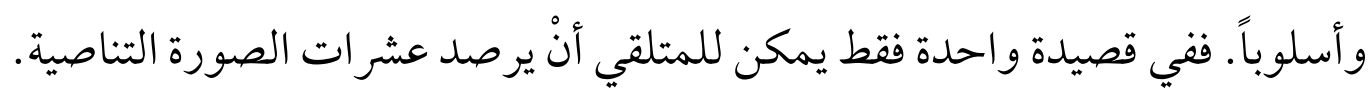

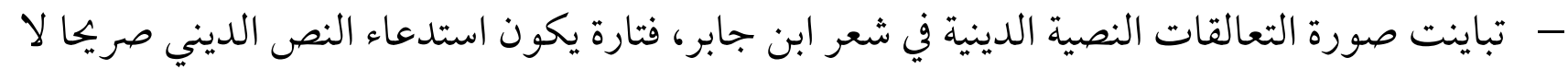

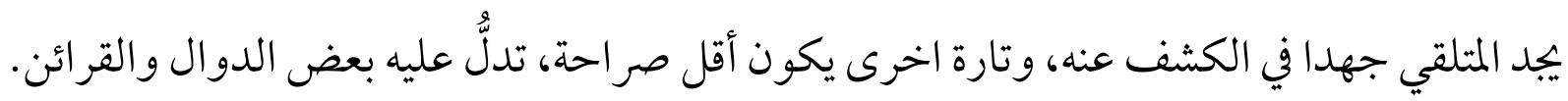


- قلم) جاءت النصوص القرآنية نختلفة الدلالة في نصوص ابن جابر الشعرية، إذ كان الشاعر يوظف النص القرآني بالمعنى نفسه؛ ليكسب نصَّه قوة وقداسة وخلودا.

- - حرص الشاعر على استدعاء الصفات القرآية الفاضلة، لاسيا في مدحه الرسول الله الكرام رضي الله عنهم، ولعله أراد بذلك أن تكون نصو صه الشعرية صادقة، ليس فيها غلو أو ابتداع.

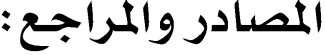

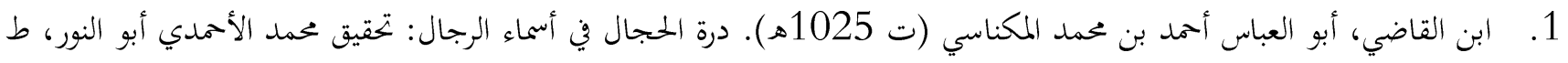

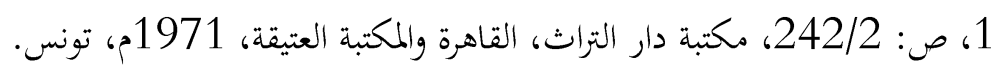
2.

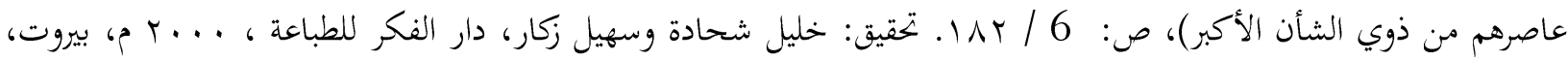
لبنان.

3. ابن منظور، محمد بن مكرم. لسان العرب، ط3، مادة (ننص) ص: 163/14، دار احياء التراث العربي، بيروت. لبنان.

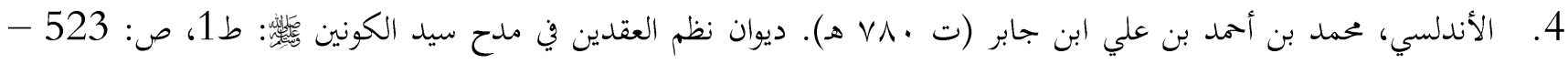

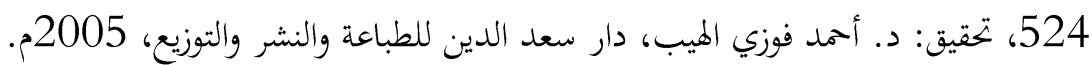

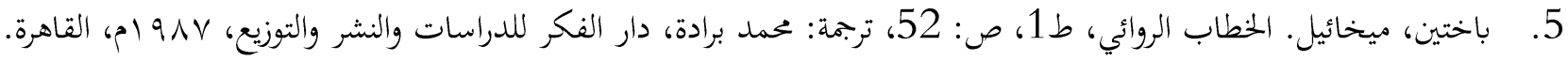

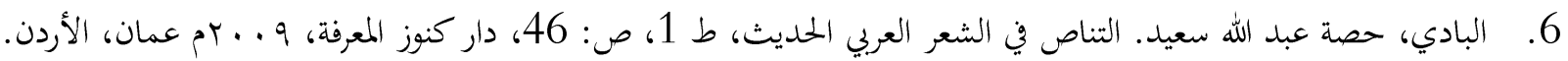

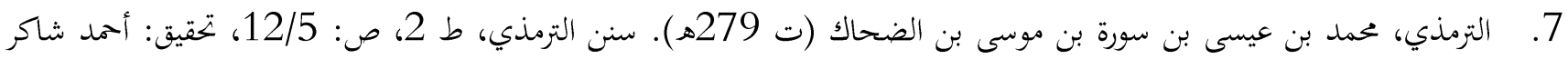

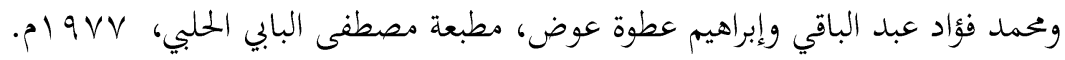

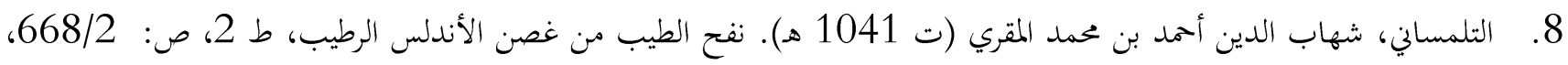
تحقيق إحسان عباس، دار صادر للطباعة والنشر، 1968 م. بيروت، لبنان.

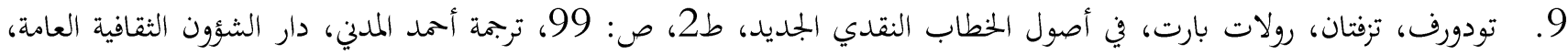

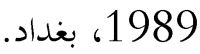
10. ثامر، فاضل. الصوت الآخر، ط1، ص: 28، دار الشؤون الثقافية العامة، 1992، بغداد.

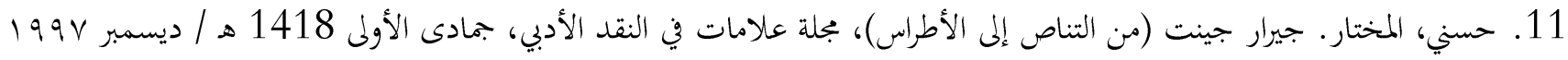

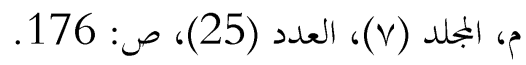

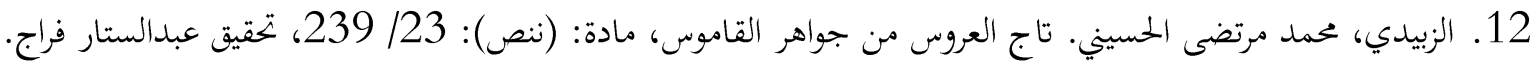

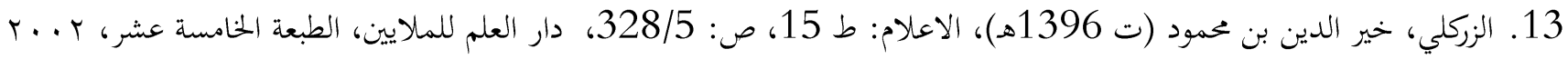
م، بيروت، لبنان. 


$$
\text { 14. الزبي، د. أحمد. التناص نظرياً وتطبيقاً، ص: 15، مؤسسة عمون للنشر والتوزيع، 2000م، عمان - الأردن. }
$$

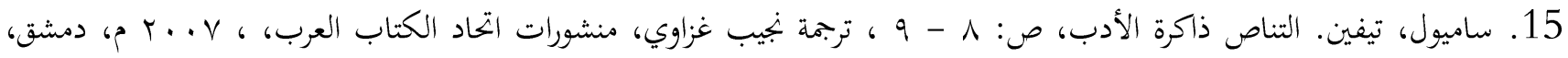

16. السخاوي، شمس الدين محمد بن عبدالرممن بن محمد (ت r .9 هـ). المقاصد الحسنة في بيان كثير من الأحاديث المشتهرة على

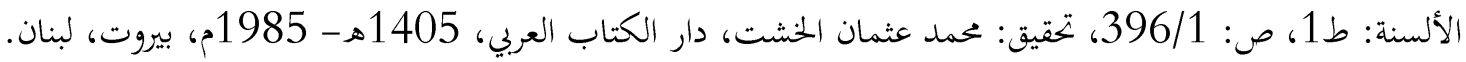

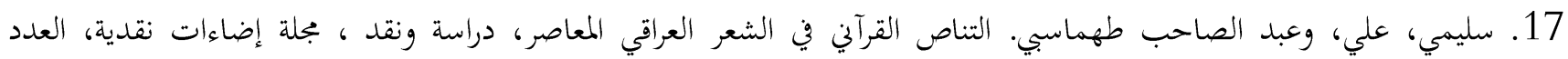

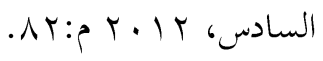

18. السيوطي، جلال الدين عبد الرمن (ت 911 هـ). بغية الوعاة في طبقات اللغويين والنحاة، ط 1 1، ص:34/1 - 35، تحقيق محمد أبو الفضل إبراهيم، مطبعة البابي الحلبي، 1964 1964م، القاهرة. 19. الصبيحي، محمد الأخضر ـ مدخل الى علم النص وبجالات تطبيقه، ص: 101، 104، الدار العربية للعلوم، ناشرون.

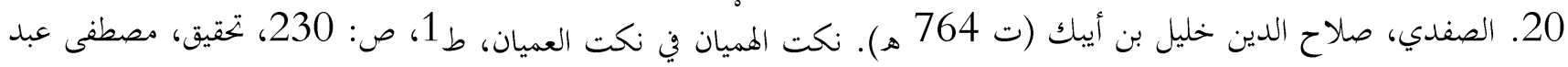

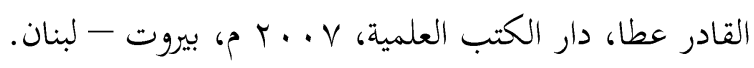

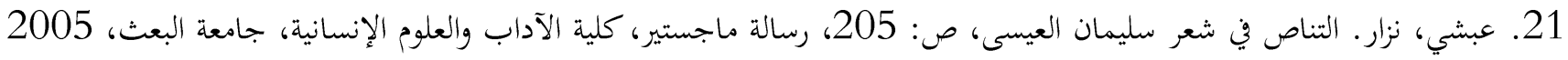

$$
\text { م. مصع، سوريا. }
$$

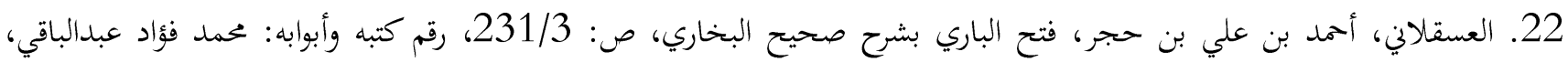

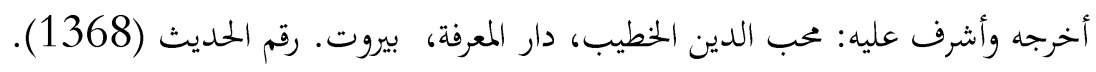

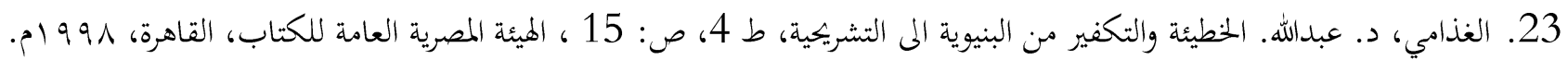

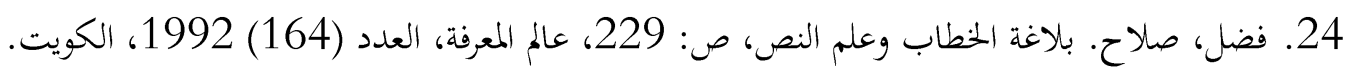

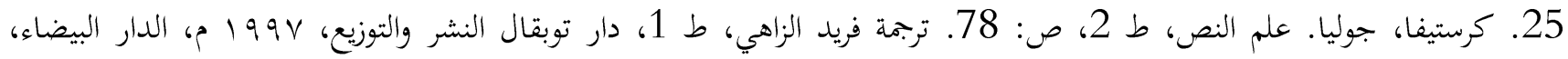
المغرب. 26. النيسابوري، أبو الحسين مسلم بن الحجاج (ت البك هـ). صحيح مسلم، ط 16، ص: 1854/4، تقيق: محمد فؤاد عبد الباقي،

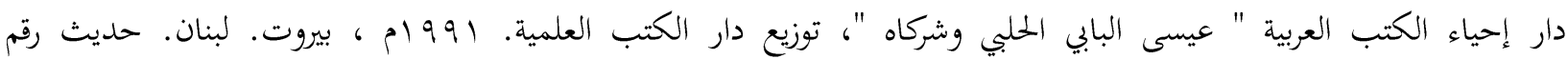
.(2382)

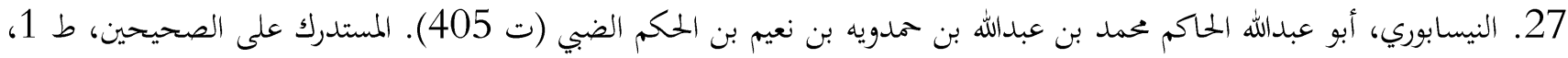

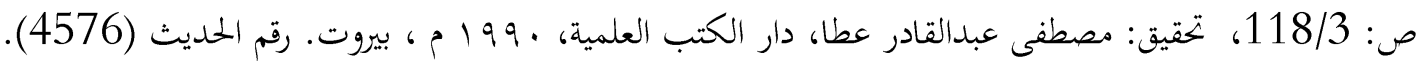

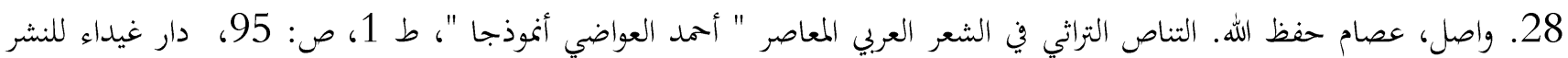
والتوزيع، 11 . بام. عمان - الأردن. 


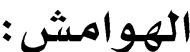

(1) ابن منظور، محمد بن مكرم. لسان العرب، ط3، مادة (نص): 163/14، دار احياء التراث العربي، بيروت. لبنان.

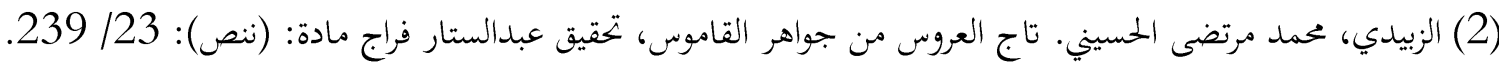

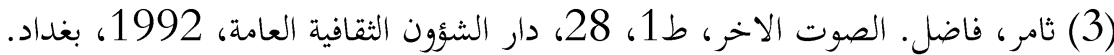

(4) تودورف، تزفتان، رولات بارت، في أصول الخطاب النقدي الجديد، ترجمة أحمد المدني، دار الشؤون الثقافية العامة-بغداد، ط2، الثاد،

1989 99

(5) فضل، صلاح. بلاغة الخطاب وعلم النص، 229، عالم المعرفة، العدد (164) 1992، الكولئ الكويت.

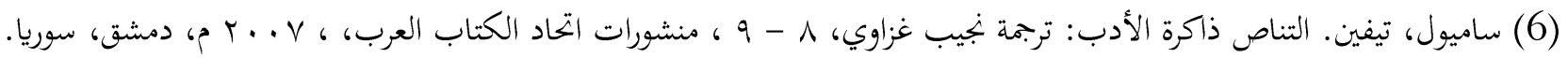

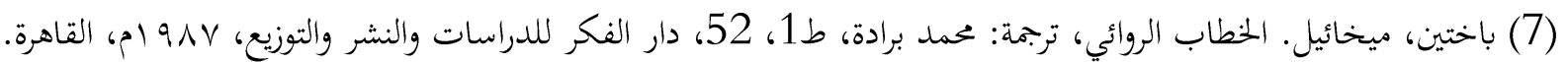

(8) كرستيفا، جوليا. علم النص، ترجمة فريد الزاهي، ط 2، 78. دار توبقال النشر والتوزيع، لو 199 1 م، الدار البيضاء، المغرب.

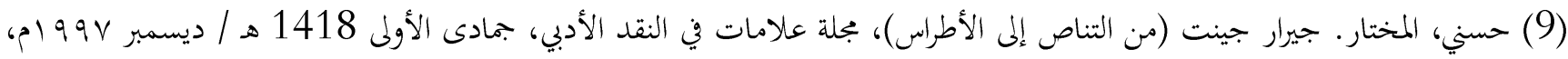

الجملد (v)، العدد (25)، ص: 176.

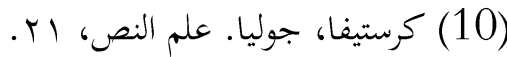

(11) الصبيحي، محمد الأخضر. مدخل الى علم النص وبجالات تطبيقه، ص: 101، 101، الدار العربية للعلوم، ناشرون.

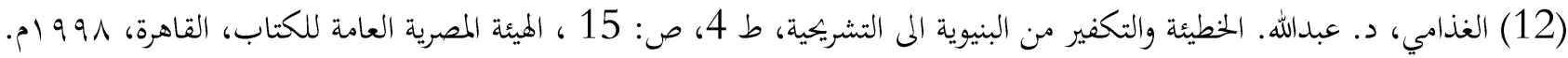

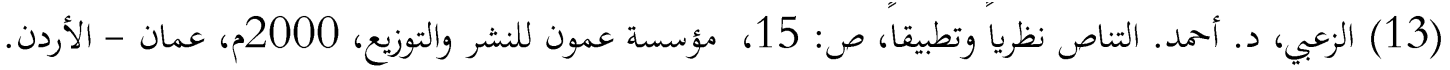

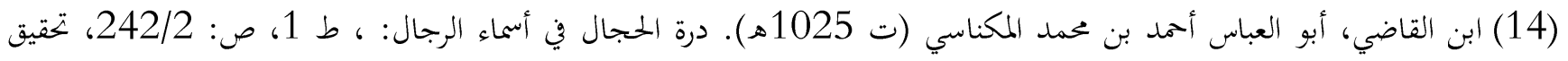

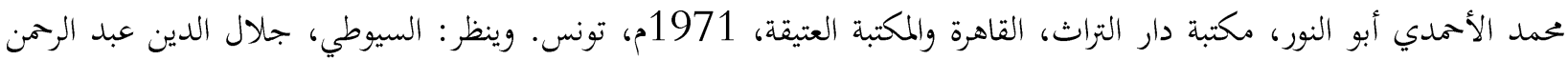

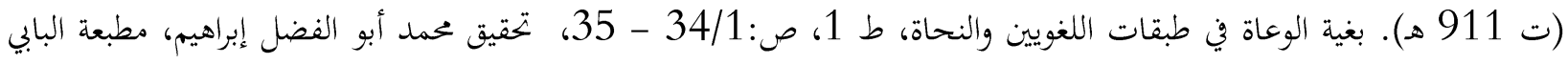

الحلبي، 1964م، القاهرة.

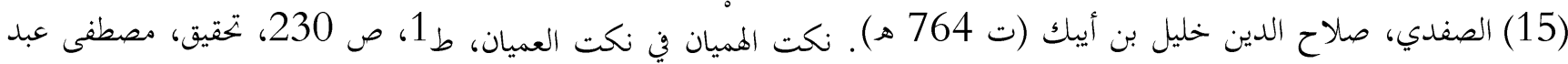

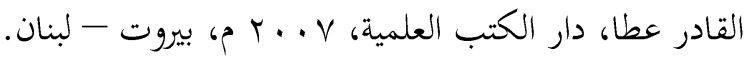

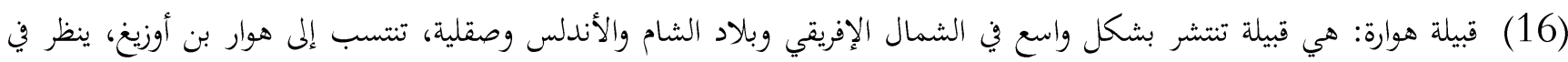

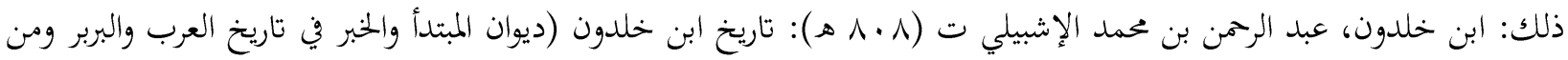

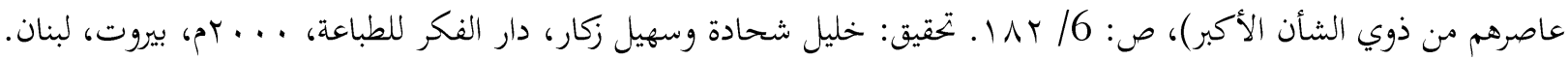

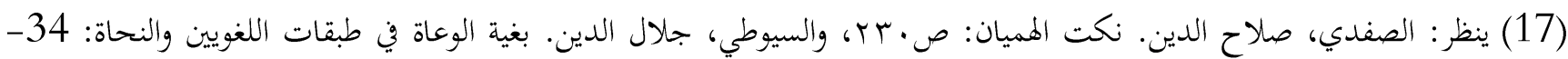

(18) الزركلي، خير الدين بن محمود (ت 1396هـ)، الأعلام: ط 15، ص: 328/5، دار العلم للملايين، ؟ . . بم، بيروت، لبنان. 
(19) ينظر: التلمساني، شهاب الدين أحمد بن محمد المقري (ت 41. 1 هـ). نفح الطيب من غصن الأندلس الرطيب، ط 2، ص: 668/2، تحقيق إحسان عباس، دار صادر للطباعة والنشر، 9619 1 م. بيروت، لبنان.

(20) سليمي، علي، وعبد الصاحب طهماسبي. التناص القرآي في الشعر العراقي المعاصر، دراسة ونقد ، بجلة إضاءات نقدية، العدد

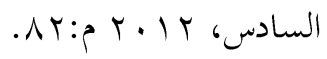

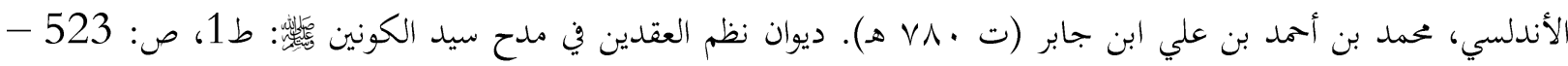

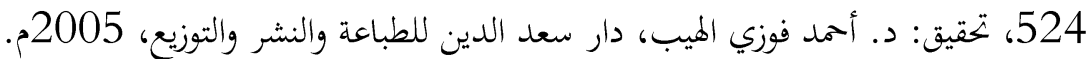

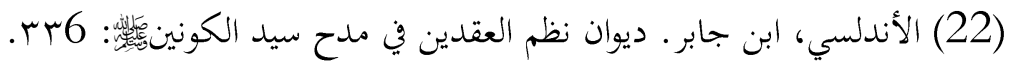

(23) عبشي، نزار. التناص في شعر سليمان العيسى، ص: 205، رسالة ماجستير، كلية الآداب والعلوم الإنسانية، جامعة البعث،

$$
\text { 2005م. حصص، سوريا. }
$$

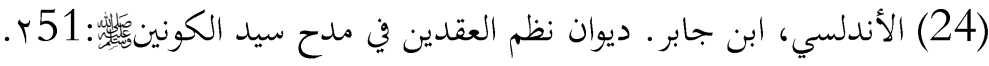

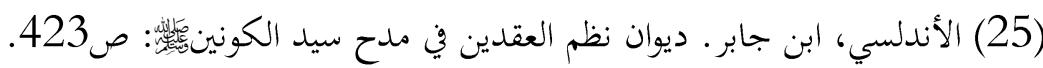
(26) واصل، عصام حفظ الله. التناص التراثي في الشعر العربي المعاصر " أحمد العواضي أنموذجا "، ط 1، ص: 95، دار غيداء للنشر

$$
\text { والتوزيع، } 11 \text { • ب ب. عمان - الأردن. }
$$

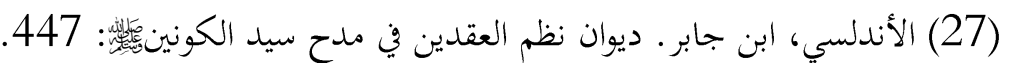

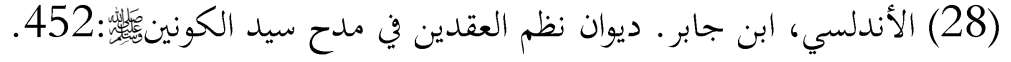

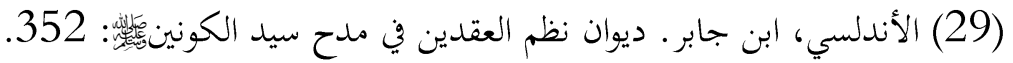

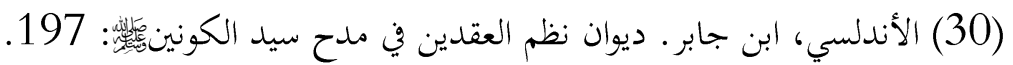

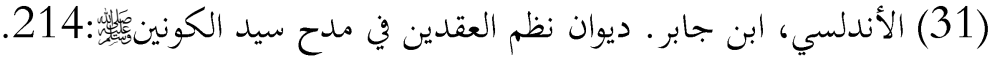

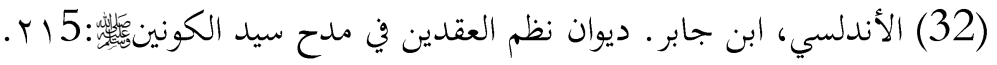

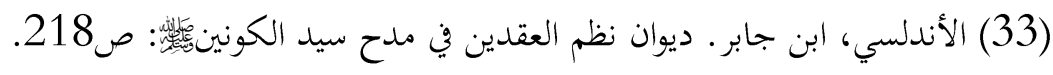

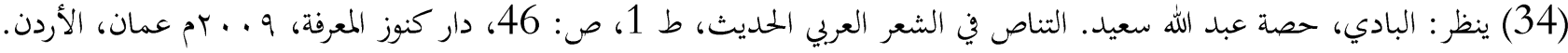

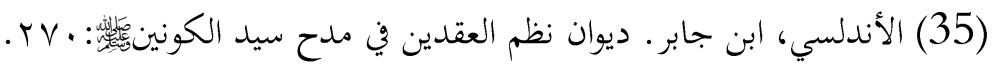

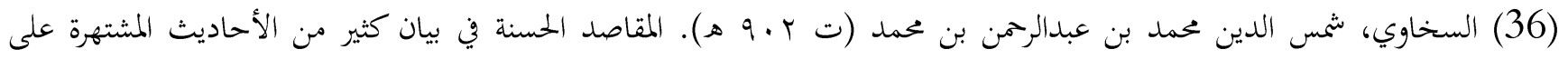
الألسنة: ط1، ص: 396/1، تحقيق: محمد عثمان الخشت، دار الكتاب العربي، 1405هـ - 1985م، بيروت، لبنان، رقم الحديث

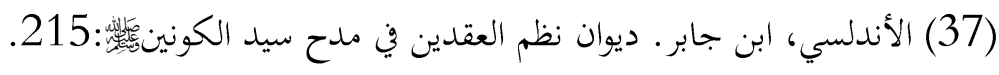

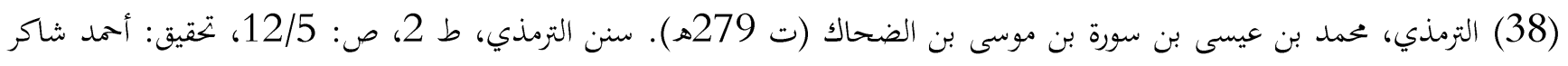

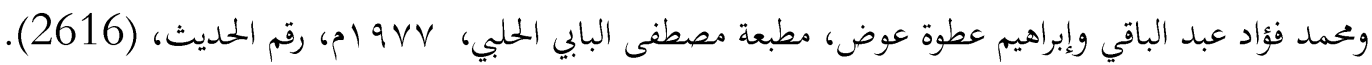

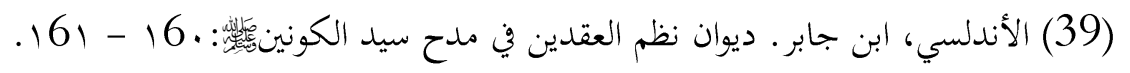




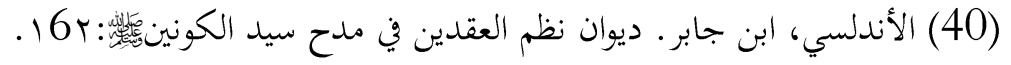

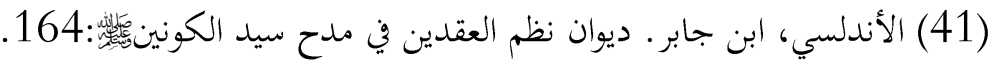

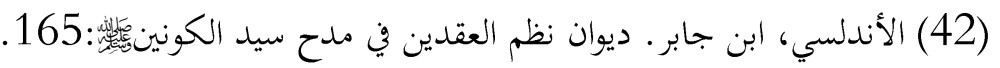

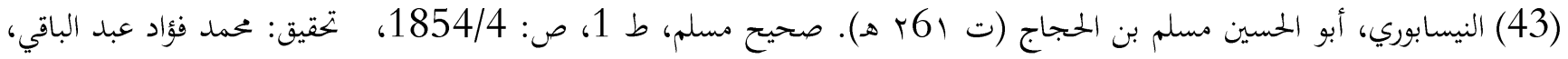

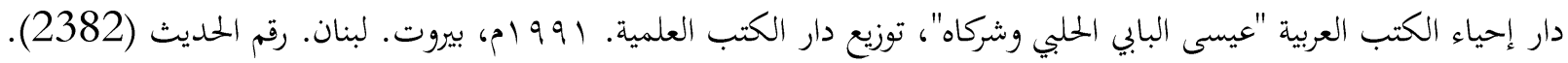

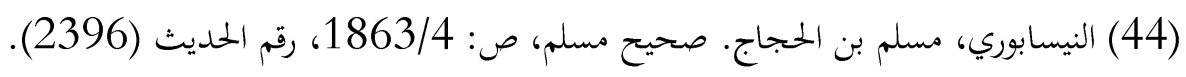

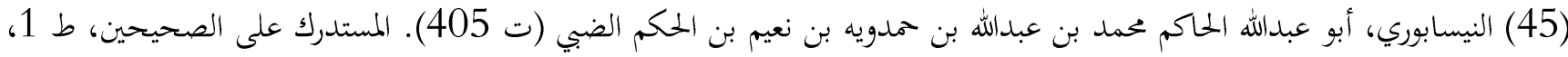

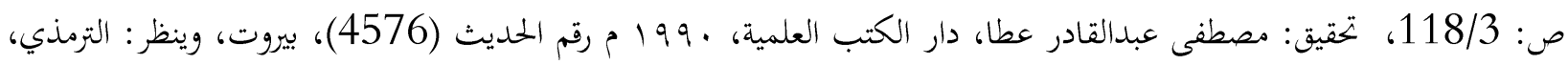

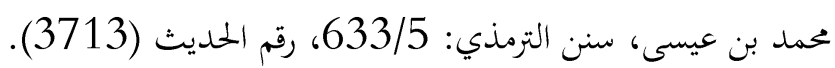

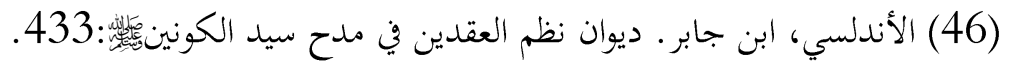

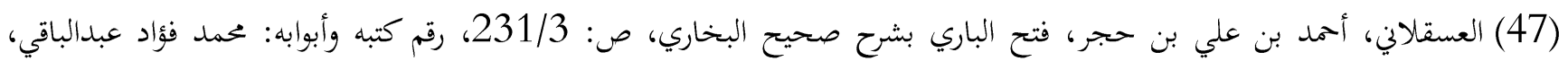

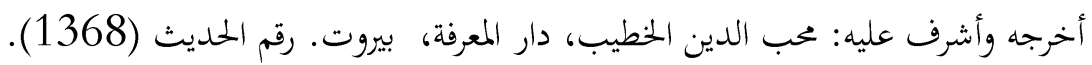

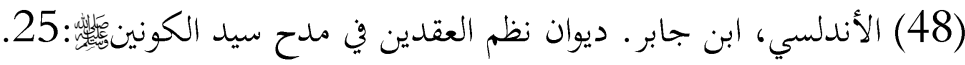

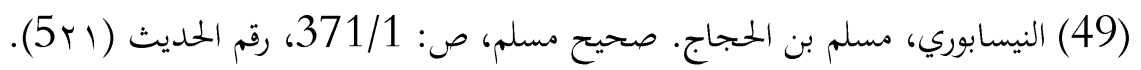

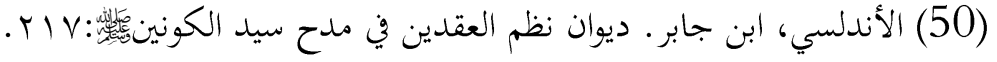

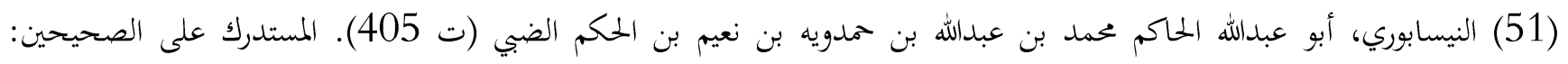

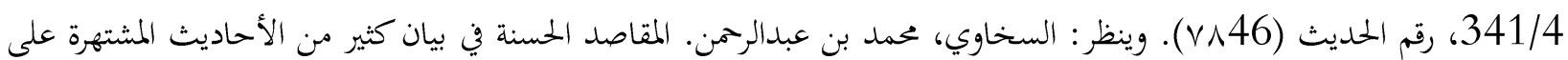

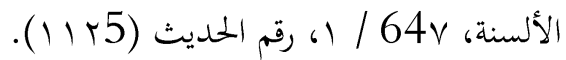

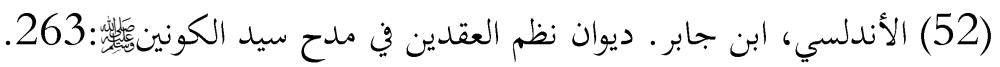

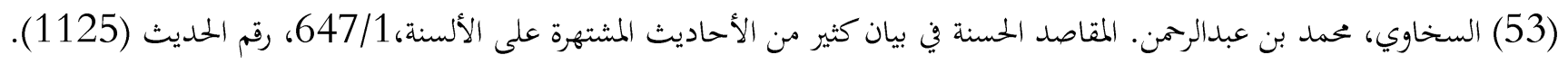

